\title{
Corporate Social Responsibility and Access to Finance
}

\section{Citation}

Cheng, Beiting, loannis loannou, and George Serafeim. "Corporate Social Responsibility and Access to Finance." Strategic Management Journal (forthcoming).

\section{Permanent link}

http://nrs.harvard.edu/urn-3:HUL.InstRepos:9887635

\section{Terms of Use}

This article was downloaded from Harvard University's DASH repository, and is made available under the terms and conditions applicable to Open Access Policy Articles, as set forth at http:// nrs.harvard.edu/urn-3:HUL.InstRepos:dash.current.terms-of-use\#OAP

\section{Share Your Story}

The Harvard community has made this article openly available.

Please share how this access benefits you. Submit a story.

\section{Accessibility}




\title{
CORPORATE SOCIAL RESPONSIBILITY AND ACCESS TO FINANCE
}

\author{
Beiting Cheng, Ioannis Ioannou and George Serafeim*
}

\begin{abstract}
In this paper, we investigate whether superior performance on corporate social responsibility (CSR) strategies leads to better access to finance. We hypothesize that better access to finance can be attributed to a) reduced agency costs due to enhanced stakeholder engagement and b) reduced informational asymmetry due to increased transparency. Using a large cross-section of firms, we find that firms with better CSR performance face significantly lower capital constraints. Moreover, we provide evidence that both of the hypothesized mechanisms, better stakeholder engagement and transparency around CSR performance, are important in reducing capital constraints. The results are further confirmed using several alternative measures of capital constraints, a paired analysis based on a ratings shock to CSR performance, an instrumental variables and also a simultaneous equations approach. Finally, we show that the relation is driven by both the social and the environmental dimension of CSR.
\end{abstract}

Keywords: corporate social responsibility, sustainability, capital constraints, ESG (environmental, social, governance) performance, stakeholder engagement, disclosure

\footnotetext{
${ }^{*}$ Beiting Cheng is a doctoral candidate at Harvard Business School, Ioannis Ioannou is an Assistant Professor at London Business School, and George Serafeim is an Assistant Professor at Harvard Business School. George Serafeim acknowledges the support of the Division of Faculty Research and Development of the Harvard Business School. We are grateful to Robert Eccles, Philipp Kruger, Costas Markides, and seminar participants at the annual United Nations Principles for Responsible Investment conference in Sweden, Academy of Management, and Warwick University. Contact emails: becheng@hbs.edu, iioannou@london.edu, gserafeim@ @hbs.edu.
} 


\section{INTRODUCTION}

In recent decades, a growing number of academics as well as top executives have been allocating a considerable amount of time and resources to Corporate Social Responsibility (CSR) strategies - i.e. the voluntary integration of social and environmental concerns in their companies' operations and in their interaction with stakeholders (European Commission, 2001). According to the latest UN Global Compact - Accenture CEO study (2010), 93 percent of the 766 participant CEOs from all over the world declared CSR as an "important" or "very important" factor for their organizations' future success. ${ }^{1}$ Despite this large amount of attention, a fundamental question still remaining unanswered is whether CSR leads to value creation, and if so, in what ways? The extant research so far has failed to give a definitive answer (Margolis, Elfenbein and Walsh, 2007). In this paper, we argue for and provide empirical evidence for one specific mechanism through which CSR may generate value in the long-run: by lowering the idiosyncratic constraints that a firm faces in financing operations and strategic projects and allowing it to undertake profitable investments that it would otherwise bypass.

In this study, by "capital constraints" we refer to those market frictions that may prevent a firm from funding all desired (i.e. NPV-positive) investments. This inability to obtain finance may be "due to credit constraints or inability to borrow, inability to issue equity, dependence on bank loans, or illiquidity of assets" (Lamont et al., 2001). Prior studies found that capital constraints play an important role in strategic decision-making by directly affecting the firm's ability to undertake major investment decisions (Stein, 2003) and also, by influencing the firm's capital structure choices (e.g., Hennessy and Whited, 2007). Moreover, capital constraints are associated with a firm's subsequent stock market performance (e.g. Lamont et al., 2001).

\footnotetext{
1 “A New Era of Sustainability. UN Global Compact-Accenture CEO Study 2010" last accessed July $28^{\text {th }}, 2010$ at: (https://microsite.accenture.com/sustainability/research and insights/Pages/A-New-Era-of-Sustainability.aspx)
} 
The thesis of this paper is that firms with better CSR performance face lower capital constraints. This is due to several reasons. First, superior CSR performance is linked to better stakeholder engagement, limiting the likelihood of short-term opportunistic behavior (Benabou and Tirole, 2010; Eccles et al., 2012) and as a result reducing overall contracting costs (Jones, 2005). Second, firms with better CSR performance are more likely to disclose their CSR activities to the market (Dhaliwal et al., 2011) to signal their long-term focus and differentiate themselves (Spence, 1973; Benabou and Tirole, 2010). CSR reporting creates a positive feedback loop: a) increases transparency around the social and environmental impact of companies, and their governance structure and b) may change the internal control system that further improves the compliance with regulations and the reliability of reporting. Therefore, the increased availability and quality of data about the firm reduces the informational asymmetry between the firm and investors (e.g. Botosan, 1997; Khurana and Raman, 2004; Hail and Leuz, 2006; Chen et al., 2009; El Ghoul et al., 2011), leading to lower capital constraints (Hubbard, 1998). In sum, because of lower agency costs through stakeholder engagement and increased transparency through CSR reporting, we hypothesize that a firm with superior CSR performance will face lower capital constraints.

To investigate the impact of CSR on capital constraints, we use a panel data set from Thompson Reuters ASSET4 for 2,439 publicly listed firms during the period 2002 to 2009. Thompson Reuters ASSET4 rates firms' performance on three dimensions (“pillars”) of CSR: social, environmental and corporate governance. The main dependent variable of interest is the “KZ index", first advocated by Kaplan and Zingales (1997) and subsequently used extensively in the corporate finance literature (e.g. Lamont et al., 2001; Baker et al., 2003; Almeida et al., 2004; Bakke and Whited, 2010; Hong et al., 2011) as a measure of capital constraints. 
The results confirm that firms with superior CSR performance face lower capital constraints. We test and confirm the robustness of the results in several ways. First, we substitute the $\mathrm{KZ}$ index with several other measures of capital constraints including an indicator variable for stock repurchase activity, an equal-weighted KZ index, the SA Index (Hadlock and Pierce, 2010), and the WW Index (Whitted and Wu, 2006). Moreover, we construct measures and test empirically for the two hypothesized mechanisms - stakeholder engagement and CSR disclosure - and we find that both variables are significantly related to capital constraints in the predicted direction. Furthermore, in subsample analysis, we find that the link between CSR performance and capital constraints is economically larger and highly significant for the subsample of firms that are most capital constrained contradicting, as we explain, the argument that CSR is a "luxury good". Importantly, the results remain unchanged when we use the introduction of ESG ratings as a shock to CSR performance (Chatterji and Toffel, 2010) and subsequently investigate changes in the CSR Index and capital constraints for a paired sample of firms. We also implement a two-stage feasible efficient Generalized Method of Moments (GMM) estimation and a three-stage least squares simultaneous equations model with validity-tested instruments, mitigating potential endogeneity concerns or correlated omitted variables issues and increasing confidence in the directionality of our results. Finally, we explore the impact of the three components of CSR individually and find that the impact on capital constraints is driven by both social and environmental performance, suggesting that both social and environmental issues are relevant for investors.

\section{Corporate Social Responsibility}

Numerous studies have investigated the link between CSR and financial performance through a theoretical as well as an empirical lens. In particular, research rooted in neoclassical economics 
argued that CSR unnecessarily raises a firm's costs, putting the firm in a position of competitive disadvantage vis-à-vis its competitors (Friedman, 1970; Aupperle et al., 1985; McWilliams and Siegel, 1997; Jensen, 2002). Predominantly based on agency theory, some studies have argued that employing valuable firm resources to engage in CSR results in significant managerial benefits rather than financial benefits to the firm's shareholders (Brammer and Millington, 2008).

In contrast, other scholars have argued that CSR can have a positive impact by providing better access to valuable resources (Cochran and Wood, 1984; Waddock and Graves, 1997), attracting and retaining higher quality employees (Turban and Greening, 1997; Greening and Turban, 2000), allowing for better marketing of products and services (Moskowitz, 1972; Fombrun, 1996), creating unforeseen opportunities (Fombrun et al., 2000), and contributing towards gaining social legitimacy (Hawn et al., 2011). Furthermore, CSR may function in similar ways as advertising does, increasing demand for products and services and/or reducing consumer price sensitivity (Dorfman and Steiner, 1954; Navarro, 1988; Sen and Bhattacharya, 2001; Milgrom and Roberts, 1986) and even enabling firms to develop intangible assets (Gardberg and Fomburn, 2006; Hull and Rothernberg, 2008; Waddock and Graves, 1997). From a stakeholder theory perspective (Freeman, 1984; Freeman et al., 2007; Freeman et al., 2010), which suggests that CSR includes managing multiple stakeholder ties concurrently, scholars have argued that CSR can mitigate the likelihood of negative regulatory, legislative or fiscal action (Freeman, 1984; Berman et al., 1999; Hillman and Keim, 2001), attract socially conscious consumers (Hillman and Keim, 2001), or attract financial resources from socially responsible investors (Kapstein, 2001).

Empirical work investigating the link between CSR and corporate financial performance, measured by various accounting or stock market measures, has resulted in contradictory findings, 
ranging from a positive to a negative relation, to a $\mathrm{U}$-shaped or even to an inverse- $\mathrm{U}$ shaped relation (Margolis and Walsh, 2003; Margolis, Elfenbein and Walsh, 2007). According to McWilliams and Siegel (2000), such conflicting results were due to "several important theoretical and empirical limitations" (p.603) of prior studies; some have argued that prior work suffered from "stakeholder mismatching" (Wood and Jones, 1995), the neglect of "contingency factors" (e.g. Ullmann, 1985), "measurement errors" (e.g. Waddock and Graves, 1997) and, omitted variable bias (Aupperle et al., 1985; Cochran and Wood, 1984; Ullman, 1985).

More recent work focuses on understanding the role of capital markets as an intermediate mechanism though which CSR can create long-term value. For example, Lee and Faff (2009) show that firms with high CSR scores have lower idiosyncratic risk, while Goss (2009) shows that firms with low CSR scores are more likely to experience financial distress. Moreover, Ioannou and Serafeim (2010a) show a positive impact of CSR on sell-side analysts' recommendations while Goss and Roberts (2011) find that firms with the worst CSR scores pay between 7 and 18 basis points more on their bank debt compared to firms with higher scores. Relatedly, Dhaliwal et al. (2011) find that the voluntary disclosure of CSR activities leads to a reduction in the firm's cost of capital, while attracting dedicated institutional investors and analyst coverage. El Ghoul et al. (2011) focus on a sample of US firms and find that firms with better CSR scores exhibit lower cost of equity capital.

In this paper, we contribute to this emerging literature that investigates the relation between capital markets and socially responsible firms by focusing on the critical impact that CSR has on idiosyncratic firm capital constraints. Unlike prior studies that mainly focused on US firms only, our findings are based on a broad sample of firms originating from 49 countries. Moreover our study adds to prior work by considering other forms of capital constrains beyond 
the cost of equity or debt, including the inability to borrow, the inability to issue equity, the dependence on bank loans, or the illiquidity of assets (Lamont et al., 2001). More importantly, this paper identifies the mechanisms through which better CSR performance contributes to lower capital constraints. As we explain in the following section, understanding the impact of CSR on capital constraints is important given that prior literature has documented the key role of capital constraints in strategic investment decisions (Stein, 2003).

\section{Capital Constraints}

Companies undertake profitable (i.e. NPV-positive) investments with the goal of achieving superior performance and competitive advantage. The ability to finance such strategic investments though is directly linked to the idiosyncratic capital constraints that each firm faces. The investment function is derived from the firm's profit-maximizing optimization and postulates that investment depends on the marginal productivity of capital, interest rate, and tax rules (Summers et. al., 1981; Mankiw, 2009). As Stein (2003) notes, according to this paradigm "nothing else should matter: not the firm's mix of debt and equity financing, nor its reserves of cash and securities, nor financial market 'conditions', however defined" (p.125). Yet subsequent studies that examine equity and debt markets show that cash flow (i.e. a firm's internal funds) also plays a key role in determining the firm's level of investment (Blundell et. al., 1992; Whited, 1992; Hubbard and Kashyap 1992). Importantly, some studies show that financially constrained firms are more likely to diminish investments in a wide range of strategic activities (Hubbard, 1998; Campello et al., 2010), including investments in inventory (Carpenter et al., 1998) as well as investments in R\&D activities (Himmelberg and Petersen, 1994; Hall and Lerner, 2010), in pricing for market share (Chevalier, 1995) and in labor hoarding during recessions (Sharpe, 1994), thus significantly and adversely the capacity of the firm to grow over time. 
In terms of firm survival and performance moreover, it is critical to understand that capital constrained firms are forced to forgo investments that they would otherwise make. In other words, these are investment opportunities that are profitable (i.e. NPV-positive) yet they are not pursued due to financing frictions. It follows then that, all else equal, the relaxation of capital constraints for such firms would enable them to undertake otherwise profitable investments and, in expectation at least, to improve their performance. Recently for example, Faulkender and Petersen (2012) use the American Jobs Creation Act (AJCA) of 2004 as a temporary shock to the cost of internal financing, and find that indeed AJCA resulted in large increases in investment but only among the subset of firms which were capital constrained (p. 2).

A second set of studies has explored how capital constraints affect the firm's entry and exit decisions into markets or industries. More specifically, using personal tax-return data on entrepreneurs, Holtz-Eakin, Joulfaian, and Rosen (1994a) find that the size of an individual's inheritance - regarded as an exogenous shock to one's wealth - had a significant positive effect on the probability of becoming an entrepreneur. A follow-up paper (Holtz-Eakin, Joulfaian, and Rosen 1994b) shows that firms founded by entrepreneurs with a larger inheritance (thus, lower capital constraints) are also more likely to survive. Aghion, Fally and Scarpetta (2007) document a similar mechanism using firm-level data from 16 economies, comparing new firm entry and their subsequent post-entry growth trajectory.

A third stream of literature accounting for both incumbents and new entrants (see Levine (2005) for a comprehensive review) argues that capital constraints affect smaller, newer and riskier firms relatively more, channeling capital to where the marginal return is highest. As a result, countries with better-functioning financial systems that can ease such constraints, experience faster industrial growth. Given the idiosyncratic levels of constraints faced by 
companies of various sizes, scholars turned to capital constraints as an explanation for why small companies pay lower dividends, become more highly levered and grow more slowly (Cooley and Quadrini 2001; Cabral and Mata 2003). For example, Carpenter and Petersen (2002) show that the asset growth of small U.S. firms is constrained by their internal capital, and that firms who are able to raise additional external funds enjoy a higher growth rate. Becchetti and Trovato (2002) find qualitatively similar results using a sample of Indian firms, and Desai, Foley and Forbes (2008) confirm the same relation in a currency crisis setting. Finally, Beck et al. (2005), using survey data from global companies, document that firm performance is vulnerable to various financial constraints and that small companies are disproportionately affected due to tighter limitations. In sum, the literature to date has revealed that seeking ways to relax capital constraints is crucial to the firm-level survival and growth, industry-level expansion and even country-level development.

\section{The Link between CSR and Capital Constraints}

Based on neoclassical economic assumptions that postulate a flat supply curve for funds in the capital market at the level of the risk-adjusted real interest rate, Hennessy and Whited (2007) argue that "a CFO can neither create nor destroy value through his financing decisions in a world without frictions". However, in reality, the supply curve for funds is effectively upward sloping rather than horizontal - at levels of capital that exceed the firm's net worth -because of market imperfections such as informational asymmetries (Greenwald, Stiglitz and Weiss 1984; Myers and Majluf 1984) and agency costs (Bernanke and Gertler 1989, 1990). In other words, when the likelihood of agency costs is high and the amount of capital that the firm requires for investments exceeds its net worth (and it is therefore uncollateralized), capital providers are compensated for their information (and/or monitoring) costs through pricing capital a higher 
interest rate. ${ }^{2}$ Consequently, the greater these market frictions are, the steeper the supply curve and the higher the cost of external financing.

It follows then, that the adoption and implementation of firm strategies that reduce informational asymmetries or reduce the likelihood of agency costs make the supply curve for funds effectively less steep. Therefore, better access to funds lowers the idiosyncratic capital constraints the firm is facing, favorably impacting its strategic objectives by allowing it to undertake major investments that would not otherwise have been profitable, and/or by influencing the capital structure choices of the firm (e.g., Hennessy and Whited, 2007).

We argue that the adoption and implementation of CSR strategies that lead to superior CSR performance result in lower idiosyncratic capital constraints for the firm because of two complementary mechanisms. First, superior CSR performance captures the firm's commitment to and engagement with stakeholders on the basis of mutual trust and cooperation (Jones, 1995; Andriof and Waddock, 2002). Consequently, as Jones (1995) argues, "because ethical solutions to commitment problems are more efficient than mechanisms designed to curb opportunism, it follows that firms that contract with their stakeholders on the basis of mutual trust and cooperation [...] will experience reduced agency costs, transaction costs and costs associated with team production". Such agency and transaction costs according to Jones (2005) would include "monitoring costs, bonding costs, search costs, warranty costs and residual losses." Moreover, superior engagement with stakeholders can enhance a firm's revenue or profit generation - also contributing towards the persistence of superior profitability (Choi and Wang, 2009) - through higher quality of relationship with customers, business partners and among employees; which in turn improves interaction with customers and new product development. ${ }^{3}$ In

\footnotetext{
${ }^{2}$ For a full exposition of the model, based on neoclassical assumptions, see Hubbard (1998), p. 195-198.

${ }^{3}$ We thank an anonymous referee for suggesting this point.
} 
other words, superior stakeholder engagement may directly limit the likelihood of short-term opportunistic behavior (Benabou and Tirole, 2010; Eccles et al., 2012), and it also represents a more efficient form of contracting with key stakeholders (Jones, 1995) that could lead to enhanced revenue or profit generation, which in turn is rewarded by the markets.

Secondly, prior studies have shown that firms with superior CSR performance are more likely to publicly disclose their CSR strategies by issuing sustainability reports (Dhaliwal et al., 2011) and are also more likely to provide assurance of such reports by third parties, therefore increasing the credibility of such reports (Simnett et al., 2009). Consequently, CSR reporting: a) increases transparency with regards to the social and environmental impact of companies, and their governance structure and b) may lead to changes in internal control system that further improves the compliance with regulations and the reliability of reporting. As a result, the extended availability of credible data about the firm's CSR strategies, in addition to its financial disclosures, further reduces informational asymmetry and results in lower capital constraints (Hubbard, 1998). Moreover, the resulting changes in internal managerial practices (Ioannou and Serafeim, 2011) may also reduce the likelihood of agency costs in the form of short-termism.

To summarize, we postulate that firms with superior CSR performance will face lower idiosyncratic capital constraints because of two mechanisms: a) reduced agency costs and revenue/profit generating potential resulting from more effective stakeholder engagement and $b$ ) reduced informational asymmetry resulting from more extended and more credible CSR disclosure practices and transparency.

\section{DATA AND SAMPLE}

Dependent Variable: The KZ index of capital constraints 
We follow the extant literature in corporate finance (e.g. Lamont et al. 2001; Almeida et al., 2004; Bakke and Whited, 2010) in measuring the level of capital constraints by constructing the $\mathrm{KZ}$ index for every firm-year pair in our sample utilizing estimates from Kaplan and Zingales (1997). As reported in Lamont et al. (2001), Kaplan and Zingales (1997) classified firms into discrete categories of capital constraints and then employed an ordered logit specification to relate their classifications to accounting variables. Consistent with prior literature, in our empirical approach, we use their regression coefficients to construct the $\mathrm{KZ}$ index in every year and for each firm, consisting of a linear combination of five accounting ratios: a) cash flow to total capital, b) the market to book ratio, c) debt to total capital, d) dividends to total capital, and e) cash holdings to capital. Higher values of the $\mathrm{KZ}$ index imply that the firm is more capital constrained (see part I of the appendix for a more detailed exposition).

As a robustness check, we also construct an equally-weighted $\mathrm{KZ}$ index, where the five accounting variables still enter the specification linearly, but they are assigned equal weights (as opposed to being weighted with the Kaplan and Zingales (1997) estimates). Furthermore, and in light of recent criticism of the KZ Index in the corporate finance literature (e.g. Hadlock and Pierce, 2010) we use three alternative measures of capital constraints as follows: a) an indicator variable for the absence of stock repurchase activity (Hong et al. 2011), b) the SA Index suggested by Hadlock and Pierce (2010), and c) the WW Index suggested by Whitted and Wu (2006). All of our firm-level data were collected from Worldscope. We winsorize each of the five elements of the $\mathrm{KZ}$ index at the 99 percentile to avoid extreme ratios. We follow the same procedure when we construct the SA and the WW index of capital constraints. Independent Variables: Measuring CSR and the Thomson Reuters ASSET4 Dataset ${ }^{4}$

\footnotetext{
${ }^{4}$ This section draws extensively from various public documents found at the firm's website ( $\underline{w w w}$. asset4.com) as well as personal communication with our contacts at the firm.
} 
Prior studies have suggested a number of measures for CSR performance: forced-choice survey instruments (Aupperle, 1991; Aupperle et al., 1985), the Fortune reputational and social responsibility index or Moskowitz' reputational scales (Bowman and Haire, 1975; McGuire et al., 1988; Preston and O'Bannon, 1997), content analysis of corporate documents (Wolfe, 1991), behavioral and perceptual measures (Wokutch and McKinney, 1991), and case study methodologies (Clarkson, 1991).

For our empirical analysis, and to measure CSR performance, we use a panel dataset with environmental, social and governance (ESG) performance scores obtained from Thomson Reuters ASSET4; a Swiss-based company that specializes in providing objective, relevant, auditable and systematic ESG information and investment analysis tools to professional investors who built their portfolios by integrating ESG (non-financial) data into their traditional investment analysis. It is estimated that investors representing more than $€ 2.5$ trillion assets under management use the ASSET4 data, including prominent investment houses such as BlackRock. Specially trained research analysts collect 900 evaluation points per firm, where all the primary data used must be objective and publically available. After gathering the ESG data every year that lacks fully accepted reporting standards worldwide - the analysts transform it into consistent units to enable quantitative analysis of this qualitative data. Indicatively, we note that: a) for environmental factors the data would typically include information on energy used, water recycled, carbon emissions, waste recycled, and spills and pollution controversies and b) for social factors the data would typically include employee turnover, injury rate, accidents, training hours, women employees, donations, and health \& safety controversies.

The data points that are collected are categorized as "drivers" or "outcomes". Drivers "track policies that cover issues such as emission reduction, human rights, and shareholder rights" 
whereas outcomes "track quantitative results such as greenhouse gas emissions, personnel turnover and highest remuneration package". Based on these data points, Thomson Reuters (ASSET4) offers a comprehensive platform for establishing customizable benchmarks (e.g. sector, country etc) for the assessment of corporate performance. Annually, these 900 data points are used as inputs to a default equal-weighted framework to calculate 250 key performance indicators (KPIs), to be further organized into 18 categories within four pillars: a) environmental performance score, b) social performance score c) corporate governance score and d) economic performance score ${ }^{5}$. In year $t$, a firm receives a $\mathrm{z}$-score for each of the pillars, benchmarking its performance against the rest of the firms based on all the information available in fiscal $t$ - 1 ; therefore, by construction, our independent variable is lagged by one year. So, our final sample is an unbalanced panel dataset where the unit of observation is the firm-year dyad and where every firm receives a score on each of these pillars in every year.

For our analysis, we use the annual environmental, social and corporate governance scores to construct a composite CSR index for every year and each focal firm. In the absence of theoretical guidance about how to weight each measure in constructing an aggregated CSR score, we follow the convention established by Waddock and Graves (1997) and Sharfman (1996), followed by Hillman and Keim (2001) and Waldman, Siegel and Javidan (2006) among others, in constructing a composite CSR index by assigning equal importance (and thus, equal weights) to each of the three pillars. ${ }^{6}$ In particular, the variable $C S R$ Index is the equally weighted average of the social, the environmental and the governance score for the focal firm for every year in our panel dataset.

\footnotetext{
${ }^{5}$ An online appendix with a detailed description of the Thomson Reuters ASSET4 dataset is available online from the authors at: http://ioannou.us/wp-content/uploads/2012/08/OnlineApp.docx

${ }^{6}$ We note that the papers cited here used the KLD database instead, but the concept of assigning equal weights to the various aspects of corporate social responsibility, is the same.
} 
We use two additional variables to test for the two theoretical mechanisms of how CSR impacts capital constraints. First, in order to capture Stakeholder Engagement we use a score directly from the ASSET4 dataset that measures the degree to which a focal company explains the formal processes in place for engagement with its stakeholders. Second, we measure ESG disclosure by identifying in our dataset all the metrics (i.e. data points) for which the focal company failed to provide information. Therefore, the variable CSR Disclosure is equal to the average of indicator variables that measure whether a company has disclosed an information item or not in any given year, and as a result it ranges from zero to one.

\section{RESULTS}

\section{Summary statistics}

Table 1 provides descriptive statistics for the entire sample. Panel A presents descriptive statistics for the multiple measures we use to capture the extent to which a focal firm is capital constrained, starting with the $K Z$ index, but also the $S A$ index, the $W W$ index, the No Repurchase Indicator an as well as for the independent variables of interest. The sample includes firm-year pairs from a total of 49 countries across the world and a large number of unique firms: 486 firms in 2002, 495 firms in 2003, 1,049 firms in 2004, 1,376 firms in 2005, 1,400 firms in 2006, 1,537 firms in 2007, 1,544 firms in 2008 and 2,191 firms in 2009. Panel B presents the distribution of observations across sectors. Three sectors - light and heavy manufacturing (2, 3) and transportation, communications, electric, gas and sanitary services (4) - represent a large portion of the total number of observations, although the remaining sectors are also populated. Panel C presents the distribution of observations across years and panel D across countries. Approximately 50 percent of the sample originates from Japan, the USA and the UK. Approximately 500 observations are firms from East and Southeast Asian countries such as 
China, Indonesia, Thailand, India, Hong Kong and Singapore, and about 100 observations are firms from Latin America. Most of the remaining observations are firms from Continental European countries.

The mean value of the $K Z$ index is 0.07 and the standard deviation is 1.46 suggesting that significant variation exists across firms regarding the idiosyncratic capital constraints they face. About half of the firms in our sample have repurchased their own stock (mean of No Repurchase indicator is 0.48 ) during the period of the study. The mean value of the $S A$ index is -1.17 and the standard deviation is 0.92 implying significant variation for this index as well. The table also suggests that relatively less variation exists for the $W W$ index. The average CSR Index in the sample is 0.52 and firms seem to perform slightly better on the Environmental and the Social, compared to the Corporate Governance dimension. The average Stakeholder Engagement in our sample varies significantly since the mean score is 46.12 and the standard deviation is 27.35 . The mean CSR Disclosure score is 0.47 . We present univariate correlations for all the variables of interest in part II of the appendix.

\section{Baseline models}

Panel A of Table 2 presents our baseline linear specifications that examine the relation between capital constraints and CSR performance. In column (1), the coefficient on CSR Index is negative and highly significant $(-1.034$, p-value $<0.01)$, suggesting that on average firms with better CSR performance face lower capital constraints. Since larger firms have better CSR performance (Ioannou and Serafeim, 2010b) and lower capital constraints (Hadlock and Pierce, 2010), the model controls for firm size as well country, industry, and year fixed effects. We measure firm size as the natural logarithm of total assets. ${ }^{7}$ The estimated relation suggests that firms that score

\footnotetext{
${ }^{7}$ We have alternatively used the natural logarithm of sales or market capitalization with no meaningful impact on our findings.
} 
on the $75^{\text {th }}$ percentile of the CSR Index have a KZ Index that is lower by 0.40 compared to firms that score on the $25^{\text {th }}$ percentile of the CSR Index. This estimate is economically significant as it is equal to approximately $28 \%$ of the standard deviation of the $K Z$ index. In column (2), we use a No Repurchase Indicator variable for the absence of stock repurchases as an alternative, albeit less coarse proxy for idiosyncratic firm capital constraints. We follow Hong et al., (2011) in calculating this indicator by deducting preferred stock reduction from expenditure on the purchase of common and preferred stocks. Again, the coefficient on CSR Index is negative and significant $(-0.401, \mathrm{p}$-value $<0.01)$. In column (3), we use an equal-weighted $K Z$ Index to test whether our results are sensitive to the empirically derived weights assigned to each of its five components in past literature. Specifically, in constructing the equal-weighted $K Z$ Index, all five ratios are first standardized to have a normal distribution with a mean of zero and a standard deviation of one, therefore eliminate differences in scale across them. The equal-weighted $K Z$ Index exhibits a high positive correlation with the weighted $K Z$ Index $(0.77$, p-value $<0.01)$, suggesting that the measure of capital constraints is only moderately affected by changing the weights on each component. The results in column (3) are consistent with the results in columns (1) and (2). and confirm that firms with better CSR performance have lower capital constraints (0.204, p-value<0.01).

In columns (4) and (5) we use alternative measures of capital constraints to provide further validity to our findings and address recent criticisms of the $K Z$ Index. In particular, we follow Hadlock and Pierce (2010) in constructing the SA Index, and Whitted and Wu (2006) in constructing the WW Index (see part II of the appendix). Columns (4) and (5) do not include Size as a control since size is used in the derivation of the dependent variable. The results suggest that the main findings are robust to these alternative measures of capital constraints; the coefficient 
on the CSR Index obtains a negative sign and it is highly significant (p-value $<0.01)$ across all specifications.

In Panel B of Table 2, we introduce firm fixed effects for all the specifications of Panel A to mitigate concerns that the results are driven by an unidentified time-invariant firm characteristic that is correlated with both the CSR index and proxies for capital constraints. For these specifications the coefficient of interest is estimated through changes over time within a focal firm. Moreover, for a particular firm to be included in this analysis, we require that we have complete data for all eight years (i.e. we generate a balanced panel of observations). ${ }^{8}$ We impose this criterion to ensure that there is enough variation in both dependent and independent variables within a firm. Consistent with columns (1) to (5), we find that firms with better CSR performance face lower capital constraints as measured by the $K Z$ Index $(-0.457$, p-value $<0.05){ }^{9}$ The estimated relation suggests that firms that score on the $75^{\text {th }}$ percentile of the CSR Index have a $K Z$ index that is lower by 0.18 compared to firms that score on the $25^{\text {th }}$ percentile of the CSR Index, with this estimate being approximately $12 \%$ of the standard deviation of the $K Z$ Index, for this subsample. Moreover, our results are confirmed when using the equal-weighted KZ Index and the WW Index as alternative measures of performance; the coefficient on CSR Index is negative and highly significant at -0.183 (p-value $<0.01$ ) and -0.017 (p-value $<0.01$ ), respectively. The findings are also confirmed when we use the No Repurchase Indicator, and the SA Index but the estimated coefficient is not significant. We note however, that in the case of the SA Index, introducing firm fixed effects substantially reduces the power of our test given the high autocorrelation of the SA index; indicatively, the adjusted R-squared is $96.6 \%$.

\footnotetext{
${ }^{8}$ We obtain similar results when we include all firms in our sample.

${ }^{9}$ Because the KZ index was developed and tested primarily within the US setting, we also performed our analysis only with US data. The results were very similar when we restricted the sample only to US firms.
} 
In unreported results, we estimated the specifications of Panel A Table 2 by including controls for lagged dependent variables three years prior to the focal year of measurement of the dependent variable. The use of the lagged dependent variable effectively controls for all historical factors that may have influenced the firm's capital constraints in the past. Our findings remain robust to these specifications as well. The coefficient on CSR index was negative and significant in all five specifications.

\section{Relation between CSR and capital constraints for different levels of capital constraints}

One potential concern with the findings presented so far is reverse causality and as a result, possible endogeneity of our CSR variable. Specifically, firms that are less capital constrained might invest in more CSR initiatives and achieve better CSR performance (Hong et al., 2011). This argument would suggest that engagement with CSR initiatives is a form of a "luxury good" that firms can afford only when they face no or very low capital constraints. If this is the case then CSR is correlated with the error term and the coefficient on the CSR Index is biased and inconsistent. In table 3 we perform subsample analyses to empirically investigate this issue. If the luxury good argument holds, one would expect the relation between CSR and capital constraints to be stronger for firms facing the lowest capital constraints. This is because for such firms a higher proportion of an additional dollar of financing will be deployed to CSR strategies compared to a firm that faces high capital constraints and which is likely to deploy that additional source of financing to other projects that are not luxury goods. We categorize the firms in our sample into three groups based on the level of capital constraints that they face (i.e. the $K Z$ Index) compared to their sector peers' located in the same country and year, and run the same baseline model as in Table 2 (column 1) interacting the CSR Index with indicator variables for each of the three groups; the Medium Constrained group constitutes the baseline category. 
The results in Table 3 show that contrary to what one would predict based on the luxury good argument, for the subgroup of firms that are least capital constrained, the coefficient of interest is positive and significant suggesting that for this group of firms the relation between CSR and capital constraints is the weakest. In contrast, for the most constrained firms the relation is the strongest. We conclude from this test that the results presented so far are unlikely to be driven primarily by reverse causality.

\section{ESG ratings as exogenous shock to CSR performance}

To test the robustness of our results to potentially yet unidentified endogeneity problems we follow Chatterji and Toffel (2010) in identifying a shock to the CSR performance of a company. More specifically, Chatterji and Toffel (2010) argue and empirically confirm that when a rating agency starts rating a firm (that it had not previously rated), it will generate a response from the firm. According to their hypothesis 1: "Firms that will receive a poor environmental rating will subsequently improve their environmental performance more than other firms will." This improvement in environmental performance, and in our case CSR performance more generally, is driven by the initiation of the rating process and it is a reaction by the company to protect its reputation. Therefore, the subsequent improvement in CSR performance is not caused by a decrease in capital constraints.

We design and implement the follow test: within the pool of companies that ASSET4 initiates coverage and within each industry-country pair, we select the company with the lowest CSR rating and we match it with another company - that ASSET4 initiated coverage on the same year and belongs in the same industry-country pair - that has the closest $K Z$ Index. Essentially with this process we are matching firms on the coverage initiation decision, country, industry and initial capital constraints. Then, we track the $K Z$ Index and CSR performance of these (paired) 
firms over the next three years. We construct the next pair of firms by selecting the firm with the second lowest CSR rating and so on until there is no more firms that we can match within the same industry-country pair that ASSET4 initiates coverage. Consistent with Chatterji and Toffel (2010), we find that firms with originally poor CSR ratings do exhibit an improvement in their subsequent ratings more so than their better rated counterparts. Importantly, and in accordance with our argument stating that improvements in CSR ratings drive a decrease in capital constraints, we find that, on average, firms with poor CSR ratings decrease their capital constraints more than their better rated (paired) firms, as they improve their CSR ratings. The results of this analysis are presented in Table 4: both the change in CSR and the KZ Index for the two groups are shown as well as the statistical significance of the differences-in-differences estimates.

\section{Instrumental variables and simultaneous equations models}

We complement the above analysis with two additional approaches: a) an instrumental variables and b) a simultaneous regressions approach. The advantage of the instrumental variables approach is that the estimated coefficients are more likely to be consistent (Wooldridge, 2002). However, the estimates from an instrumental variables approach are less efficient because the standard errors are large (Wooldridge, 2002). The advantage of the simultaneous regressions model is that it is a more efficient estimation procedure because it uses the errors from two or more equations. But the estimates are less likely to be consistent because the instruments used in both equations need to be exogenous, compared to the instrumental variables approach that requires exogenous instruments only for the endogenous variable (Wooldridge, 2002). We note that an additional issue with our data is the presence of heteroskedasticity, which we detected through a test proposed by Pagan and Hall (1983) for panel data. In the presence of 
heteroskedasticity or clustered errors, although the standard IV coefficient estimates remain consistent, their standard errors and the usual forms of the diagnostic tests are not (Baum, Schaffer and Stillman, 2003). To address this issue, we specify a GMM option in our implementation to make efficient estimation, valid inference and diagnostic testing, allowing for clustering the errors at the firm level.

We generate two instruments by calculating the average CSR Index (excluding the contribution of the focal firm) for each country-sector pair and country-year pair. ${ }^{10}$ The rationale behind these two instruments is that the firm's CSR performance is influenced by a timeinvariant component that is associated with its membership in the country-industry pair, and a time-varying component at the country level. The intuition is that a focal firm's CSR performance is systematically influenced by the CSR performance of other firms within the same industry-country pair, and by the CSR performance of other firms in the same country over time. In fact, previous research has shown that CSR performance is determined by both country and industry characteristics (Ioannou and Serafeim, 2012). Moreover, CSR performance might systematically vary over time within countries as a result of laws and regulations that mandate CSR disclosure (Ioannou and Serafeim, 2011). Because for both instruments the contribution to the CSR Index by the focal firm is excluded, the instruments vary across firms even within the same country-industry and country-year pairs. More importantly, since we are using two instruments we are able to perform a number of tests to assess their validity and their relevance.

Columns (1) and (2) of Table 5 present the results from the first and second stage of the instrumental variables regression, respectively. We report results for three post-estimation tests. First, the under-identification test is essentially an LM test of whether our equation is identified.

\footnotetext{
${ }^{10}$ Previous papers have also used as instruments the industry or country mean of the independent variable (Lev and Sougiannis, 1996; Nevo, 2000; Friedberg, 2003; Hanlon, Rajgopal, and Shevlin, 2003).
} 
In the presence of heteroskedaticity, the more traditional Anderson LM and Cragg-Donald Wald statistics are no longer valid. Instead, table 5 presents the LM and Wald versions of the Kleibergen-Paap (2006) rk statistic, which is a generalization of the more traditional tests. For our data, the model is always identified. Second, the weak identification test estimates how relevant and how strong our instruments are. In the presence of heteroskedasticity, the traditional Cragg-Donald-based F-statistic is not valid so instead, we report again the Kleibergen-Paap Walk rk F-statistic. For our sample, the F-statistic is at least 20, warranting that our instruments are relevant and strong. Finally, we report on the over-identification test. For this test, the null hypothesis is that the instruments are exogenous (uncorrelated with the error term), so if the statistic is significant and the p-value is small enough, this suggests that the instruments are not exogenous. Since the traditional Sagan test is no longer valid, we report in table 5 a Hansen's J statistic (1982), which remains consistent when the error is heteroskedastic. For our specification, the test statistics are insignificant and the p-value is very high. Therefore the null hypothesis is not rejected.

These tests show that the instruments satisfy the conditions of exogeneity and relevance and as a result they are valid. The coefficient on the CSR Index is negative and significant (2.348, p-value<0.01), suggesting that the exogenous component of the CSR performance negatively impacts capital constraints. As a robustness check, we run the same specification on a balanced panel which allowed us to include firm fixed effects in our specifications. Despite the reduction of observations to 2,616 in unreported results the coefficient on CSR Index remains negative and highly significant. We also note that in the construction of our instruments, some bias may have been introduced by the fact that some country-sector or country-year pairs were not sufficiently populated to generate a meaningful instrument. In unreported results, we drop 
those observations for which the instruments were generated in a country-sector or country-year cell with fewer than 10 observations. Our results remain virtually unchanged.

In order to eliminate any remaining endogeneity problem resulting from simultaneity bias (i.e. if the causal effects obtain in both directions), we endogenize both the CSR Index as well as the $K Z$ Index by implementing a simultaneous equations estimation method (one for each plausible causal direction). In doing so, we use the constructed instruments as explained above for the CSR Index, and by constructing similar instruments for the $K Z$ Index (i.e. the average $K Z$ Index for each country-sector pair and country-year pair). More specifically, we use a three-stage least squares (3SLS) estimation method where we first use an instrumental variables approach to produce consistent estimates and subsequently use generalized least squares (GLS) to account for correlated error terms across our two equations (Wooldridge, 2002). ${ }^{11}$ For this system of simultaneous equations to be identified, there must be at least as many non-collinear exogenous variables in the remaining system as there are endogenous right-hand-side variables in an equation (Wooldridge, 2002). This condition is satisfied in our system of equations, where there is only one right-hand-side endogenous variable in each equation, and two exogenous variables in the remaining system.

Columns (3) and (4) of Table 5 show that implementing this simultaneous equations methodology produces similar results as our baseline specifications. ${ }^{12}$ The coefficient on the CSR Index is negative and significant $(-1.545, \mathrm{p}$-value $<0.01)$. The coefficient on the $K Z$ Index is also negative and significant $(-0.048, \mathrm{p}$-value $=0.01)$. These results suggest that superior CSR performance leads to lower capital constraints but also that lower capital constraints lead to an

\footnotetext{
${ }^{11}$ To be more specific, we implement this technique using the reg3 command in the statistical package STATA.

${ }^{12}$ In unreported results, we utilized a transformed (logarithmic) version of the KZ Index to account for the fact that CSR performance could potentially be more important for the firms that are least capital constrained (i.e. a nonlinear relation). Our findings were robust to this specification as well, and therefore we do not report them here.
} 
improvement in CSR performance. However, closer inspection of the estimated coefficients reveals that CSR performance has a much higher economic effect compared to capital constraints. Firms that score on the $75^{\text {th }}$ percentile of the CSR Index have a KZ Index that is lower by 0.60 compared to firms that score on the $25^{\text {th }}$ percentile of the CSR Index, an estimate that is equal to $41 \%$ of the standard deviation of the $K Z$ index. In contrast, firms that score on the $75^{\text {th }}$ percentile

of the KZ Index have a CSR Index that is lower by 0.059 compared to firms that score on the $25^{\text {th }}$ percentile of the $K Z$ Index, an estimate that is equal to $24 \%$ of the standard deviation of the CSR Index.

\section{CSR disclosure and stakeholder engagement}

In table 6 we explore at a more fine-grained level the mechanisms through which CSR performance impacts capital constraints. In particular, we provide evidence that both Stakeholder Engagement and CSR Disclosure have a significant impact. Since firms with better stakeholder engagement also tend to have better CSR disclosure, we include the two variables individually and simultaneously in our model. Column (1) shows the estimated association between Stakeholder Engagement and the KZ index. The coefficient on Stakeholder Engagement is negative and significant $(-0.005$, $\mathrm{p}$-value $<0.01)$; firms with better stakeholder engagement face lower capital constraints. Column (2) shows that the estimated coefficient on CSR Disclosure is also negative and significant $(-4.264$, p-value $<0.01)$; firms with better CSR disclosure face lower capital constraints. Column (3) shows the estimated coefficients on Stakeholder Engagement and CSR Disclosure when both variables are included simultaneously. Both coefficients are negative and significant, suggesting that even when we hold stakeholder engagement constant, CSR disclosure has a significant association with capital constraints. Similarly, holding CSR disclosure constant, stakeholder engagement has a significant association with capital constraints. 
A change of one standard deviation in stakeholder engagement (disclosure) is associated with a change in the $\mathrm{KZ}$ index of 0.10 (0.35) suggesting that disclosure has a larger effect on capital constraints. Column (4) shows coefficient estimates when we control for the quality of financial disclosures. We include this control to mitigate concerns that the CSR Disclosure variable is capturing the effect of financial disclosures on capital constraints. We use an earnings quality measure constructed by McNichols (2002), who estimate total current accruals as a function of lag, current, and previous cash flow from operations, changes in revenues, and gross value of property plant and equipment separately for each industry-year pair. We find that, as expected, better earnings quality (lower volatility of accounting accruals) is associated with lower capital constraints. Importantly, the coefficient on CSR Disclosure remains negative and significant.

\section{Relation between CSR pillars and capital constraints}

Finally, we note that CSR comprises of three pillars: the environmental, the social, and the governance performance of a corporation. To better understand the distinct impact of these pillars on capital constraints, we estimate separate models for each one. Table 8, columns (1), (2), and (3) show that the coefficients on environmental (-0.770, p-value $<0.01)$, social $(-0.727, \mathrm{p}-$ value $<0.01)$ and governance $(-0.397, \mathrm{p}$-value $<0.01)$ performance are negative and highly significant. In column (4) we consider the effect of all three pillars simultaneously and we find that both social and environmental performances are negatively and significantly related to capital constraints. In contrast, corporate governance exhibits an insignificant relation to capital constraints after we control for the social and environmental performance of a corporation. An explanation for the weaker effect of corporate governance is that corporate governance is primarily driven by variation in nation-level institutional structures and as a result it is likely that the relation between corporate governance and capital constraints is stronger across countries 
rather than within a country. Indeed, when we remove country fixed effects from the model, the coefficient on corporate governance becomes negative and significant across all specifications.

\section{DISCUSSION AND CONCLUSION}

In this paper, we investigate whether CSR strategies affect the firm's ability to access finance in capital markets. Although it has been argued in the past that CSR may impose unnecessary costs to a firm (e.g. Galaskiewicz, 1997; Clotfelter, 1985:190; Navarro, 1988) and thus hinder its ability to access capital, here we provide evidence that in fact the reverse is true: firms with better CSR performance face lower capital constraints. We argue that this negative relation between CSR performance and capital constraints materializes via two distinct mechanisms. First, better CSR performance is associated with superior stakeholder engagement (Choi and Wang, 2009) that in turn significantly reduces the likelihood of opportunistic behavior and introduces a more efficient form of contracting with key constituents (Jones, 1995). In other words, stakeholder engagement based on mutual trust and cooperation reduces potential agency costs by pushing managers to adopt a long-term rather than a short-term orientation (Eccles, et al., 2012). Moreover, superior stakeholder engagement enhances the revenue or profit generating potential of the firm through the higher quality of relationships with customers, business partners and among employees. Secondly, firms with better CSR performance are more likely to publicly disclose their CSR activities (Dhaliwal et al., 2011) and consequently become more transparent and accountable. Higher levels of transparency reduce informational asymmetries between the firm and investors, thus mitigating perceived risk. Since the literature to date has argued that market frictions such as informational asymmetries and agency costs are the main reasons why firms face upward sloping supply curves in the capital markets, our results show that firms with better CSR performance face a capital supply curve that is effectively less steep. 
These results have implications for the current debate on whether, and importantly in what ways, CSR initiatives lead to value creation. Here, we document that firms with better CSR performance are better positioned to obtain financing in the capital markets. In turn, relaxation of capital constrains positively impacts the ability of firms to undertake profitable strategic investments that otherwise they would not, and stock market performance (e.g., Lamont et al., 2001).

With this study we contribute to an emerging literature within CSR that highlights the important role that capital markets play in evaluating the potential for long-run value creation by firms that adopt CSR strategies (e.g. Lee and Faff, 2009; El Ghoul et al., 2010; Goss and Roberts, 2011). Allocating scarce financial capital to their most productive uses is the fundamental role that financial markets play and in this paper we show that CSR has a significant impact on this capital allocation process: market participants are more willing to allocate scarce capital resources to firms with better CSR performance. Moreover, by disaggregating the CSR performance into its components, we are able to show at a more fine-grained level that both the social and the environmental aspect of CSR activities reduce capital constraints.

With our work we also contribute to the extant literature on capital constraints. Prior studies in this area typically consider a portfolio of financially constrained versus a portfolio of financially unconstrained firms and investigate how the two portfolios exhibit different sensitivities of investment to either cash flow (Fazzari, Hubbard and Petersen, 1988; Kaplan and Zingales, 1997; Hubbard, 1998; Cleary, 1999; Alti, 2003; Gatchev, Pulvino and Tarhan 2010) or to non-fundamental movements in stock prices (Baker, Stein and Wurgler, 2003). However, few studies (e.g. Lamont et al., 2001) have investigated which firms are more likely to be financially unconstrained and what characteristics, if any, the firms in each portfolio share. Our paper 
contributes to this literature by showing that firms that engage in CSR activities face lower capital constraints, thus identifying tangible firm characteristics that are linked to the capital constraints a firm faces.

We recognize a number of limitations to our work. Firms could be in a position to game CSR ratings so as to gain access to the increasingly available SRI funds. This is surely plausible but unlikely due to a number of reasons. First, company-reported data is all but one of the many sources that are being used by Thompson Reuters ASSET4 to gather information. The list of sources would also include NGOs (and NGO websites), stock exchange filings, and independent news sources. As much as the company could 'game' their own reporting, it is unlikely that it would be able to influence to the same degree all of these third-party sources. Therefore, there is a significant degree of triangulation that occurs across numerous information originators.

Second, the Thompson Reuters ASSET4 data have been used extensively for investment purposes by professionals and thus have been 'verified', to an extent, by the capital markets. In fact, it is estimated that investors representing more than $€ 2.5$ trillion assets under management use the ASSET4 data, including major investment houses. Furthermore, according to Thomson Reuters, "every answer to every data point question goes through a multi-step verification and process control, which includes a series of data entry checks, automated quality rules and historical comparisons, in order to ensure a high level of accuracy, timeliness and quality". This later issue also relates to a second potential limitation of this study: the quality of our data. Whereas a comprehensive validity test of this new dataset falls outside the scope of this paper, this is surely one possible avenue through which our work could be extended in the future. Especially when compared to existing studies and datasets, and accounting for our own extensive conversations with Thompson Reuters, we maintain a sufficient amount of confidence in the data. 
Another potential issue with our work relates to the emergence of the SRI market and how such funds may influence the capital markets and CSR ratings. First we note that despite the impressive growth of SRI funds in recent years, when compared to total assets under management globally, the level of SRI funds is still relatively small. As an additional robustness check, we constructed a country-level indicator variable capturing the existence (or lack thereof) of an SRI stock index in every country of our sample. We used this control variable as a proxy for the availability of SRI funds, and across all specifications, the coefficient remained insignificant. As SRI funds grow over time and in importance, future work adopting a more dynamic approach could seek to understand their potential impact on both the functioning of capital markets as well as the construction of CSR ratings.

Moreover, with regards to a potential link between SRIs and our independent variable, the CSR Index, we argue that although plausible, it is unlikely that investor behavior may be driving managerial decision-making. Since stakeholder relations and CSR actions more broadly take several years to build, and materialize in terms of profitability, the probability of a large enough SRI base retaining ownership for a sufficiently long amount of time to originate an organizational shift towards CSR strategies is relatively low. This would also require SRIs themselves to engage with the company over a long period of time in such a way as to actively push the corporation towards better CSR practices. In other words, it appears more likely that SRI funds will be attracted to organizations that score high on the CSR dimensions rather than SRI funds directly influencing firm practices, directing them towards being more socially responsible.

While we show that superior CSR performance may relax idiosyncratic capital constraints for firms, several issues remain open for future research. First, using data at the level 
of strategic projects, it would be interesting to explore whether, and in what ways, increased access to capital affects the type of strategic investments that firms decide to undertake. For example, do firms with better CSR performance pursue strategic projects that are more long-term oriented and more likely to incorporate environmental and social issues in their objectives? Second, whereas capital constraints is one important aspect of capital markets, more research needs to be undertaken in this domain for a better understanding of how capital markets perceive, evaluate and reward or punish firms that voluntarily engage in CSR initiatives. Moreover, since we do find some evidence that capital constraints may in fact affect CSR performance, future research could adopt a more dynamic approach, and investigate over a longer time frame how the causal relationship evolves in the long-run, particularly so for firms that are most constrained with low CSR performance, after they decide to undertake such investments in CSR initiatives.

Finally, in a business environment where an increasing number of CEOs consider CSR to be strategically critical, and where the general public increasingly appreciates or even demands transparent, honest and ethical business practices, our results have important managerial implications. We suggest that managers that are able to develop successful CSR strategies and, by extension, engage productively with key stakeholders can generate tangible benefits for their firms in the form of better access to financing.

\section{REFERENCES}

Aghion, P., Fally, T., and Scarpetta, S., 2007. Credit constraints as a barrier to the entry and post-entry growth of firms. Economic Policy, 22(52): 731-779.

Almeida, H., Campello, M., and Weisbach, M.S., 2004. The cash flow sensitivity of cash. Journal of Finance, 59: 1777-1804

Alti, A., 2003. How sensitive is investment to cash flow when financing is frictionless? Journal of Finance, 58: 707722

Andriof, J. and Waddock, S.A., 2002. Unfolding stakeholder engagement. In Andriof, J.,Waddock, S.A.,Husted, B.W. and Rahman, S.S. (Eds), Unfolding Stakeholder Thinking: Theory, Responsibility and Engagement, Greenleaf Publishing, Sheffield, p. 19-42.

Aupperle, K. E., 1991. The use of forced-choice survey procedures in assessing corporate social orientation. In J. E. Post (Ed.), Research in corporate social performance and policy, 12: 269-280, Greenwich, CT: JAI Press, United States. 
Aupperle, K.E., Carroll, A.B., and Hatfield, J.D. 1985. An empirical examination of the relationship between corporate social responsibility and profitability. Academy of Management Journal, 28: 446-463.

Baker, M., Stein, J.C., and Wurgler, J., 2003. When does the market matter? Stock prices and the investment of equity-dependent firms. The Quarterly Journal of Economics 118: 969-1005.

Bakke, T.E., and Whited, T.M., 2010. Which firms follow the market? An analysis of corporate investment decisions. Review of Financial Studies, 23(5): 1941-1980.

Baum, C.F., Schaffer, M.E., and Stillman, S., 2003. Instrumental variables and GMM: Estimation and testing. Working Paper, Boston College.

Becchetti, L., and Trovato, G., 2002. The determinants of growth of small and medium sized firms. The role of the availability of external finance. Small Business Economics, 19(4): 291-306.

Beck, T., Demirguc-Kunt, A., Laeven, L., and Levine, R., 2005. Financial and legal constraints to growth: Does firm size matter? Journal of Finance, 60(1): 137-177.

Benabou, R. and Tirole, J., 2010. Individual and corporate social responsibility. Economica, 77(305): 1-19

Berman, S. L., Wicks, A.C., Kotha, S., and Jones, T. M., 1999. Does stakeholder orientation matter? The relationship between stakeholder management models and firm financial performance. The Academy of Management Journal, 42(5): 488-506.

Bernanke, B., and Gertler, M., 1989. Agency costs, net worth, and business fluctuations. American Economic Review, 79: 14-31.

Bernanke, B., and Gertler, M., 1990. Financial fragility and economic performance. Quarterly Journal of Economics, 105: 97-114.

Blundell, R., Bond, S., Devereux M., and Schiantarelli, F., 1992. Investment and Tobin's Q: Evidence from company panel data. Journal of Econometrics 51: 233-257.

Botosan, C., 1997. Disclosure Level and the Cost of Equity Capital. The Accounting Review, 72: 323-349.

Bowman, E.H., and Haire, M., 1975. A strategic posture toward corporate social responsibility. California Management Review, 18(2): 49-58.

Brammer, S. \& Millington, A. 2008. Does it pay to be different? An analysis of the relationship between corporate social and financial performance. Strategic Management Journal, 29(12): 1325-1343.

Cabral, L., and Mata., J., 2003. On the evolution of the firm size distribution: Facts and theory. American Economic Review, 93: 1075-1090.

Campello, M., Graham, J.R., and Harvey, C.R., 2010. The real effects of financial constraints: Evidence from a financial crisis. Journal of Financial Economics, 97(3): 470-487.

Carpenter, R.E., Fazzari, S.M., and Petersen, B.C., 1998. Financing constraints and inventory investment: A comparative study with high-frequency panel data. Review of Economics and Statistics, 80: 513-519.

Carpenter, R., and Petersen, B., 2002. Is the growth of small firms constrained by internal finance? Review of Economics and Statistics, 84(2): 298-309.

Carroll, A.B., 1979. A three-dimensional conceptual model of corporate performance. The Academy of Management Review, 4(4): 497-505.

Chatterji, A.K. and Toffel, M.W. 2010. How firms respond to being rated. Strategic Management Journal, 31(9): 917-945

Chava, S., 2010. Socially responsible investing and expected stock returns, Working Paper, Georgia Institute of Technology.

Chen, K., Chen, Z., and Wei, K., 2009. Legal protection of investors, corporate governance, and the cost of equity capital. Journal of Corporate Finance, 15: 273-289

Chevalier, J.A., 1995. Capital structure and product-market competition: empirical evidence from the supermarket industry. American Economic Review, 85: 415-435

Choi, J., and Wang, H., 2009. Stakeholder relations and the persistence of corporate financial performance. Strategic Management Journal, 30: 895-907

Clarkson, M.B.E., 1991. Defining, evaluating, and managing corporate social performance: The stakeholder management model. In J. E. Post (Ed.), Research in corporate social performance and policy, 331-358. Greenwich, CT: JAI Press, United States.

Cleary, S., 1999. The relationship between firm investment and financial status. Journal of Finance 54: 673-692.

Clotfelter, C., 1985. Federal tax policy and charitable giving. Chicago: University of Chicago Press, United States.

Cochran, P.L., and Wood, R.A., 1984. Corporate social responsibility and financial performance. Academy of Management Journal, 27: 42-56

Cooley, T. F., and Quadrini, V., 2001. Financial markets and firm dynamics. American Economic Review, 91: 12861311. 
Derwall, J. and Verwijmeren, P., 2007. Corporate social responsibility and the cost of equity capital, Working Paper Desai, M.A., Foley, C.F., and Forbes, K.J., 2008. Financial Constraints and Growth: Multinational and Local Firm Responses to Currency Depreciations. Review of Financial Studies, 21(6): 2857-2888.

Dhaliwal, D., Li, O.Z., Tsang, A.H., and Yang, Y.G., 2011. Voluntary non-financial disclosure and the cost of equity capital: The case of corporate social responsibility reporting, The Accounting Review, 86(1): 59-100.

Dorfman, R. and Steiner, P. O., 1954. Optimal advertising and optimal quality. The American Economic Review, 44(5): 826-836.

Eccles, R., Ioannou, I., and Serafeim, G. 2012. The Impact of a Corporate Culture of Sustainability on Corporate Behavior and Performance. Harvard Business School Working Paper.

El Ghoul, S., Guedhami, O., Kwok, C.C.Y., and Mishra, D.R., 2011. Does corporate social responsibility affect the cost of capital? Journal of Banking and Finance, 35 (9): 2388-2406.

European Commission (Commission of the European Communities). 2001. Promoting a European Framework for Corporate Social Responsibilities, COM (2001) 366 final, Brussels.

Faulkender, M., and Petersen, M. 2012. Investment and capital constraints: Repatriations under the American Jobs Creation act, working paper

Fazzari, S. M., Hubbard, G., and Petersen, B.C., 1988. Finance constraints and corporate investment. Brookings Paper on Economic Activity, 141-195.

Fombrun, C.J., 1996. Reputation: Realizing value from the corporate image. Boston, MA: Harvard Business School Press, United States.

Fombrun, C. J., Gardberg, N. A., and Barnett, M. L., 2000. Opportunity platforms and safety nets: Corporate citizenship and reputational risk. Business and Society Review, 105(1): 85-106.

Freeman, R. E., 1984. Strategic Management: A stakeholder perspective. Boston, MA: Piman, United States.

Freeman, R. E., Harrison, J. S., and Wicks, A. C., 2007. Managing for stakeholders: survival, reputation, and success. New Haven, CT: Yale University Press, United States.

Freeman, R. E., Harrison, J. S., Wicks, A. C., Parmar, B. L., de Colle, S., 2010. Stakeholder theory: the state of the art. Cambridge University Press, New York, United States.

Friedberg, L., 2003. The impact of technological change on older workers: evidence from data on computers. Industrial and Labor Relations Review, 56 (3): 511-529.

Friedman, M., 1970. The social responsibility of business is to increase its profits. New York Times Magazine, 13 Sept., 32 (33):122-126.

Galaskiewicz, J., 1997. An urban grants economy revisited: Corporate charitable contributions in the Twin Cities, 1979-81, 1987-89. Administrative Science Quarterly, 42(3): 445-471.

Gardberg, N.A. and Formbrun, C.J., 2006. Corporate citizenship: Creating intangible assets across institutional environments. Academy of Management Review, 31(2): 329-346.

Gatchev, V. A., Pulvino, T., and Tarhan, V., 2010. The interdependent and intertemporal nature of financial decisions: an application to cash flow sensitivities. Journal of Finance, 65: 725-763.

Goss, A. 2009. Corporate Social Responsibility and Financial Distress. Proceedings of the Administrative Sciences

Association of Canada.

Goss, A., and Roberts, G.S., 2011. The impact of corporate social responsibility on the cost of bank loans. Journal of Banking and Finance, forthcoming

Greening, D. W. and Turban, D. B., 2000. Corporate social performance as a competitive advantage in attracting a quality workforce. Business \& Society, 39(3): 254-280.

Greenwald, B., Stiglitz, J., and Weiss, A., 1984. Information imperfections and macroeconomic fluctuations. American Economic Review, 74: 194-199.

Hadlock, J.H. and Pierce, J. R., 2010. New evidence on measuring financial constraints: Moving beyond the KZ index. Review of Financial Studies, 23(5): 1909-1940.

Hail, L., and Leuz, C., 2006. International differences in cost of equity capital: Do legal institutions and securities regulations matter? Journal of Accounting Research, 44: 485-531.

Hall, B.H., and Lerner, J., 2010. The Financing of R\&D and Innovation. In: Hall, B.H., and Rosenberg, N. (eds.), Handbook of The Economics of Innovation. Elsevier, Chap 14.

Hanlon, M., Rajgopal, S., and Shevlin, T., 2003. Are executive stock options associated with future earnings? Journal of Accounting and Economics, 36: 3-43.

Hansen, L., 1982. Large sample properties of generalized method of moments estimators. Econometrica 50(3): 1029-1054. 
Hawn, O., Chatterji, A., and Mitchell, W., 2011. How operational legitimacy conditions the impact of changes in social legitimacy on firm's economic value: The Dow Jones sustainability index addition and deletion, Working paper, Duke University.

Hennessy, C. A., and Whited, T.M., 2007. How costly is external financing? Evidence from a structural estimation. Journal of Finance, 62(4): 1705-1745.

Hillman, A. J. and Keim, G. D., 2001. Shareholder value, stakeholder management, and social issues: what's the bottom line? Strategic Management Journal, 22(2): 125-139.

Himmelberg, C.P., and Petersen, B.C., 1994. R\&D and Internal Finance: A Panel Study of Small Firms in HighTech Industries. Review of Economics and Statistics, 76(1): 38-51.

Holtz-Eakin, D., Joulfaian, D., and Rosen, H. S., 1994a. Sticking it out: Entrepreneurial survival and liquidity constraints. Journal of Political Economy, 102: 53-75.

Holtz-Eakin, D., Joulfaian, D., and Rosen, H. S., 1994b. Entrepreneurial decisions and liquidity constraints. Rand Journal of Economics, 25: 334-347.

Hong, H.G., Kubik, J. D. and Scheinkman, J. A., 2011. Financial constraints on corporate goodness. Working paper at http://ssrn.com/abstract=1734164

Hubbard, R. G., and Kashyap, A. K., 1992. Internal net worth and the investment process: An application to U.S. agriculture. The Journal of Political Economy, 100(3): 506-534.

Hubbard, R.G., 1998. Capital-market imperfections and investment. Journal of Economic Literature, 36: 193-225.

Hull, C.E., and Rothenberg, A., 2008. Firm performance: The interactions of corporate social performance with innovation and industry differentiation. Strategic Management Journal, 29(7): 781-789.

Ioannou, I., and Serafeim, G., 2010a. The impact of corporate social responsibility on investment recommendations. HBS working paper at http://ssrn.com/abstract=1507874

Ioannou, I., and Serafeim, G., 2012. What drives corporate social performance? The role of nation-level institutions. Journal of International Business Studies, forthcoming

Ioannou, I., and Serafeim, G., 2011. The consequences of mandatory corporate sustainability reporting. HBS working paper at http://ssrn.com/abstract= 1799589

Jensen, M. C., 2002. Value maximization, stakeholder theory, and the corporate objective function. Business Ethics Quarterly, 12(2): 235-256.

Jones, T.M., 1995. Instrumental stakeholder theory: A synthesis of ethics and economics. Academy of Management Review, 20: 404-437

Kaplan, S. N., and Zingales, L., 1997. Do investment-cash flow sensitivities provide useful measures of financing constraints? Quarterly Journal of Economics, 112: 169-215.

Kapstein, E. B., 2001. The corporate ethics crusade. Foreign Affairs, 80(5): 105-119

Khurana, I. K., and Raman, K.K., 2004. Litigation risk and the financial reporting credibility of big 4 versus non-big 4 audits: Evidence from Anglo-American countries. The Accounting Review, 79: 473-495.

Kleibergen, F., and Paap, R., 2006. Generalized reduced rank tests using the singular value decomposition. Journal of Econometrics, 133: 97-126.

Lamont, O., Polk, C., and Saa-Requejo, J., 2001. Financial constraints and stock returns. Review of Financial Studies 14(2): 529-554.

Lee, D., and Faff, R., 2009. Corporate sustainability performance and idiosyncratic risk: A global perspective. The Financial Review, 44 (2): 213-237.

Lev, B., and Sougiannis, T., 1996. The capitalization, amortization and value relevance of R\&D. Journal of Accounting and Economics, 21: 107-138.

Levine, R., 2005. Finance and growth: theory and evidence. In: Aghion, P., and Durlauf, S. (eds), Handbook of economic growth, vol1. Elsevier, chap 12.

McNichols, M. 2002. Discussion of the Quality of Accruals and Earnings: The Role of Accrual Estimation Errors. The Accounting Review, 77 (1): 61-69.

Mankiw, N. G., 2009. Macroeconomics. Worth Publishers, chap. 17.

Margolis, J. D., and Walsh, J. P., 2003. Misery loves companies: rethinking social initiatives by business. Administrative Science Quarterly, 48(2): 268-305.

Margolis, J. D., Elfenbein, H. A., and Walsh, J. P. 2007. Does It Pay To Be Good? A Meta-Analysis and Redirection of Research on the Relationship between Corporate Social and Financial Performance, Working paper.

Milgrom, P., and Roberts, J., 1986. Price and advertising signals of product quality. The Journal of Political Economy, 94(4): 796-821.

McGuire, J. B., Sundgren, A., and Schneeweis, T., 1988. Corporate social responsibility and firm financial performance. Academy of Management Journal, 31(4): 854-872. 
McWilliams, A., and Siegel, D., 1997. The role of money managers in assessing corporate social responsibility research. The Journal of Investing, 6(4): 98-107.

McWilliams, A., and Siegel, D., 2000. Corporate social responsibility and financial performance: correlation or misspecification? Strategic Management Journal, 21(5): 603-609.

Moskowitz, M., 1972. Choosing socially responsible stocks. Business and Society Review, 1(1): 71-75.

Myers, S., and Majluf, N., 1984. Corporate financing and investment decisions when firms have information that investors do not have. Journal of Financial Economics 13, 187-221.

Navarro, P., 1988. Why do corporations give to charity? The Journal of Business, 61(1): 65-93.

Nevo, A., 2000. Mergers with differentiated products: the case of the ready-to-eat cereal industry. RAND Journal of Economics, 31 (3): 395-421.

Pagan, A.R., and Hall, D., 1983. Diagnostic tests as residual analysis. Econometric Review, 2(2): 159-218.

Preston, L.E., and O'Bannon, D. P., 1997. The corporate social-financial performance relationship: A typology and analysis. Business and Society, 36: 419-429.

Sen, S., and Bhattacharya, C. B., 2001. Does doing good always lead to doing better? Consumer reactions to corporate social responsibility. Journal of Marketing Research, 38(2): 225-243.

Sharfman, M., 1996. The construct validity of the Kinder, Lydenberg, \& Domini social performance ratings data. Journal of Business Ethics, 15(3): 287-296.

Sharfman, M. P., and Fernando, C.S., 2008. Environmental risk management and the cost of capital. Strategic Management Journal, 29(6): 569-592

Sharpe, S.A. 1994. Financial market imperfection, firm leverage, and the cyclicality of employment. American Economic Review, 84: 1060-1074

Simnett, R., Vanstraelen, A., and Chua, W.F., 2009. Assurance on sustainability reports: an international comparison. The Accounting Review, 84 (3): 937-967.

Stein, J. 2003. Agency, Information, and Corporate Investment. Handbook of the Economics of Finance, George Constantinides, Milton Harris, and Rene' Stulz, eds. (Amsterdam: Elsevier Science)

Spence, M., 1973. Job market signaling. The Quarterly Journal of Economics, 87 (3): 355-374.

Summers, L. H., Bosworth, B. P., Tobin, J., and White, P. M., 1981. Taxation and corporate investment: A q-theory approach. Brookings Papers on Economic Activity, 1981(1): 67-140.

Turban, D. B., and Greening, D. W., 1997. Corporate social performance and organizational attractiveness to prospective employees. The Academy of Management Journal, 40(3): 658-672.

Ullmann, A. A., 1985. Data in search of a theory: a critical examination of the relationships among social performance, social disclosure, and economic performance of US firms. Academy of Management Review, 10(3): 540-557.

Waldman, D., Siegel, D., and Javidan, M., 2006. Components of CEO transformational leadership and corporate social responsibility. Journal of Management Studies, 43(8): 1703-1725.

Whited, T. M., 1992. Debt, liquidity constraints, and corporate investment: Evidence from panel data. The Journal of Finance, 47(4): 1425-1460.

Whited, T. M., and Wu, G., 2006. Financial constraints risk. Review of Financial Studies, 19: 531-59

Wokutch, R. E. and McKinney, E. W., 1991. Behavioral and perceptual measures of corporate social performance. Research in Corporate Social Performance and Policy: A Research Annual: 309.

Wolfe, R. 1991. The use of content analysis to assess corporate social responsibility. In J. E. Post (Ed.), Research in corporate social performance and policy, 12: 281-307, Greenwich, CT: JAI Press, United States

Wood, D. J. and Jones, R. E., 1995. Stakeholder mismatching: A theoretical problem in empirical research on corporate social performance. International Journal of Organizational Analysis, 3: 229-267.

Wooldridge, J. 2002. Econometric Analysis of Cross Section and Panel Data, The MIT Press, Boston, MA. 
Table 1: Descriptive Statistics

Panel A: Summary Statistics

\begin{tabular}{|l|c|ccccccc||}
\hline \multicolumn{1}{|c|}{ Variable } & $N$ & Mean & Median & $\begin{array}{c}\text { Std. } \\
\text { Dev. }\end{array}$ & Min. & $\begin{array}{c}\text { 25th } \\
\text { Perc. }\end{array}$ & $\begin{array}{c}\text { 75th } \\
\text { Perc. }\end{array}$ & Max. \\
\hline KZ index & 10078 & 0.07 & 0.32 & 1.46 & -8.08 & -0.35 & 0.87 & 4.39 \\
\hline No Repurchase Indicator & 10078 & 0.48 & 0.00 & 0.50 & 0.00 & 0.00 & 1.00 & 1.00 \\
\hline SA Index & 9952 & -1.17 & -1.10 & 0.92 & -3.85 & -1.79 & -0.54 & 3.10 \\
\hline WW Index & 9819 & -0.43 & -0.43 & 0.07 & -0.67 & -0.47 & -0.38 & -0.11 \\
\hline CSR Index & 10078 & 0.52 & 0.52 & 0.24 & 0.05 & 0.33 & 0.72 & 0.98 \\
\hline Stakeholder Engagement & 9812 & 46.12 & 34.29 & $\begin{array}{r}27.3 \\
5\end{array}$ & 28.06 & 28.08 & 36.09 & 99.75 \\
\hline CSR Disclosure & 9812 & 0.47 & 0.48 & 0.09 & 0.12 & 0.42 & 0.52 & 0.73 \\
\hline Environmental & 10078 & 0.54 & 0.56 & 0.32 & 0.09 & 0.19 & 0.87 & 0.97 \\
\hline Social & 10078 & 0.53 & 0.54 & 0.31 & 0.00 & 0.23 & 0.83 & 0.99 \\
\hline Corporate Governance & 10078 & 0.49 & 0.53 & 0.31 & 0.01 & 0.18 & 0.77 & 0.99 \\
\hline Size & 10078 & 8.59 & 8.50 & 1.40 & 2.01 & 7.63 & 9.53 & 12.81 \\
\hline
\end{tabular}


Panel B: Sample Distribution across Sectors

\begin{tabular}{|c|l|c||}
\hline $\begin{array}{c}\text { SIC } \\
\text { Code }^{13}\end{array}$ & \multicolumn{1}{|c|}{ Industry Categories } & $N$ \\
\hline 1 & Mining and Construction & 1,221 \\
\hline 2 & $\begin{array}{l}\text { Manufacturing of Food, Textile, } \\
\text { Lumber, Publishing, Chemicals and } \\
\text { Petroleum Products }\end{array}$ & 2,019 \\
\hline 3 & $\begin{array}{l}\text { Manufacturing of Plastics, Leather, } \\
\text { Concrete, Metal Products, } \\
\text { Machinery and Equipment }\end{array}$ & 2,814 \\
\hline 4 & $\begin{array}{l}\text { Transportation, Communications, } \\
\text { Electric, Gas and Sanitary Services }\end{array}$ & 1,743 \\
\hline 5 & Trade & 1,080 \\
\hline 7 & $\begin{array}{l}\text { Personal, Business and } \\
\text { Entertainment Services }\end{array}$ & 924 \\
\hline 8 & Professional Services & 275 \\
\hline 9 & Public Administration & $\mathbf{1 0 , 0 7 8}$ \\
\hline & Total & \\
\hline
\end{tabular}

Panel C: Sample Distribution across Years

\begin{tabular}{||c|c|}
\hline Year & $N$ \\
\hline 2002 & 486 \\
\hline 2003 & 495 \\
\hline 2004 & 1,049 \\
\hline 2005 & 1,376 \\
\hline 2006 & 1,400 \\
\hline 2007 & 1,537 \\
\hline 2008 & 1,544 \\
\hline 2009 & 2,191 \\
\hline Total & $\mathbf{1 0 , 0 7 8}$ \\
\hline
\end{tabular}

${ }^{13}$ For a detailed list of SIC codes and what they represent, please see

http://www.osha.gov/pls/imis/sic manual.html.

Panel D: Sample Distribution across Countries

\begin{tabular}{|c|c|c|c|}
\hline Country & $N$ & Country & $N$ \\
\hline Australia & 409 & Italy & 169 \\
\hline Austria & 77 & Japan & 1,874 \\
\hline Belgium & 84 & Korea, Republic of & 62 \\
\hline Bermuda & 13 & Kuwait & 1 \\
\hline Brazil & 46 & Luxembourg & 36 \\
\hline Canada & 426 & Morocco & 2 \\
\hline Switzerland & 285 & Mexico & 32 \\
\hline Chile & 15 & Malaysia & 17 \\
\hline China & 70 & Netherlands & 175 \\
\hline $\begin{array}{l}\text { Cayman } \\
\text { Islands }\end{array}$ & 2 & Norway & 107 \\
\hline $\begin{array}{l}\text { Czech } \\
\text { Republic }\end{array}$ & 4 & New Zealand & 49 \\
\hline Germany & 361 & Philippines & 4 \\
\hline Denmark & 123 & Poland & 8 \\
\hline Egypt & 2 & Portugal & 45 \\
\hline Spain & 150 & Qatar & 2 \\
\hline Finland & 145 & Russian Federation & 42 \\
\hline France & 448 & Saudi Arabia & 11 \\
\hline $\begin{array}{l}\text { United } \\
\text { Kingdom }\end{array}$ & 1,388 & Singapore & 136 \\
\hline Greece & 65 & Sweden & 230 \\
\hline Hong Kong & 225 & Thailand & 11 \\
\hline Hungary & 3 & Turkey & 10 \\
\hline Indonesia & 10 & Taiwan & 36 \\
\hline India & 38 & United States & 2,517 \\
\hline Ireland & 74 & South Africa & 21 \\
\hline Israel & 18 & & \\
\hline \multicolumn{2}{|c|}{ Total } & \multicolumn{2}{|l|}{10,078} \\
\hline
\end{tabular}




\section{Table 2}

Capital Constraints and CSR Performance: Linear Baseline Specifications

\begin{tabular}{|c|c|c|c|c|c|c|c|c|c|c|}
\hline \multirow[b]{2}{*}{$\begin{array}{l}\text { Dependent } \\
\text { Variable }\end{array}$} & \multicolumn{5}{|c|}{ Panel A } & \multicolumn{5}{|c|}{ Panel B } \\
\hline & $\begin{array}{c}\text { KZ Index } \\
\text { (1) }\end{array}$ & $\begin{array}{c}\text { No } \\
\text { Repurchase } \\
\text { Indicator } \\
\text { (2) }\end{array}$ & $\begin{array}{l}\text { KZ Index } \\
\text { Equal- } \\
\text { weighted } \\
\quad(3) \\
\end{array}$ & $\begin{array}{l}\text { SA Index } \\
\text { (4) }\end{array}$ & $\begin{array}{c}\text { WW Index } \\
\text { (5) }\end{array}$ & $\begin{array}{c}\text { KZ Index } \\
\text { (6) }\end{array}$ & $\begin{array}{c}\text { No } \\
\text { Repurchase } \\
\text { Indicator } \\
\text { (7) }\end{array}$ & $\begin{array}{l}\text { KZ Index } \\
\text { Equal- } \\
\text { weighted } \\
\quad(8) \\
\end{array}$ & $\begin{array}{c}\text { SA Index } \\
\text { (9) }\end{array}$ & $\begin{array}{c}\text { WW Index } \\
\text { (10) }\end{array}$ \\
\hline CSR Index & $\begin{array}{c}-1.034 * * * \\
(0.120)\end{array}$ & $\begin{array}{c}-0.401 * * * \\
(0.109)\end{array}$ & $\begin{array}{c}-0.204 * * * \\
(0.035)\end{array}$ & $\begin{array}{c}-2.025 * * * \\
(0.065)\end{array}$ & $\begin{array}{c}-0.155 * * * \\
(0.005)\end{array}$ & $\begin{array}{c}-0.457 * * \\
(0.204)\end{array}$ & $\begin{array}{l}-0.587 \\
(0.368)\end{array}$ & $\begin{array}{c}-0.183 * * * \\
(0.059)\end{array}$ & $\begin{array}{c}-0.084 \\
(0.061)\end{array}$ & $\begin{array}{c}-0.017 * * * \\
(0.006)\end{array}$ \\
\hline Size & $\begin{array}{c}0.222 * * * \\
(\mathbf{0 . 0 2 7})\end{array}$ & $\begin{array}{c}-0.079 * * * \\
(\mathbf{0 . 0 2 1})\end{array}$ & $\begin{array}{c}0.067 * * * \\
(\mathbf{0 . 0 0 8 )}\end{array}$ & & & $\begin{array}{c}0.124 \\
(0.110)\end{array}$ & $\begin{array}{c}0.247 \\
(0.175)\end{array}$ & $\begin{array}{l}-0.011 \\
(0.034)\end{array}$ & & \\
\hline Constant & $\begin{array}{c}-0.973 * * * \\
(\mathbf{0 . 1 6 6 )}\end{array}$ & $\begin{array}{c}0.445 \\
(\mathbf{0 . 7 7 0})\end{array}$ & $\begin{array}{c}-0.244 \\
(\mathbf{0 . 1 8 7})\end{array}$ & $\begin{array}{c}-0.354 * \\
(\mathbf{0 . 1 9 7})\end{array}$ & $\begin{array}{l}-0.265 \\
(0.000)\end{array}$ & $\begin{array}{l}-0.921 \\
(1.313)\end{array}$ & $\begin{array}{l}-1.631 \\
(1.562)\end{array}$ & $\begin{array}{c}0.344 \\
(0.409)\end{array}$ & $\begin{array}{c}-2.658 * * * \\
(0.066)\end{array}$ & $\begin{array}{c}-0.296 * * * \\
(0.002)\end{array}$ \\
\hline $\begin{array}{l}\text { Country FE } \\
\text { Industry FE } \\
\text { Year FE } \\
\text { Firm FE } \\
\text { Observations } \\
\text { Adjusted R- } \\
\text { squared }\end{array}$ & $\begin{array}{c}\text { Yes } \\
\text { Yes } \\
\text { Yes } \\
\text { No } \\
10,078 \\
0.213\end{array}$ & $\begin{array}{c}\text { Yes } \\
\text { Yes } \\
\text { Yes } \\
\text { No } \\
10,017 \\
\text { (Pseudo) } \\
0.142\end{array}$ & $\begin{array}{c}\text { Yes } \\
\text { Yes } \\
\text { Yes } \\
\text { No } \\
10,078 \\
0.175\end{array}$ & $\begin{array}{c}\text { Yes } \\
\text { Yes } \\
\text { Yes } \\
\text { No } \\
9,952 \\
0.5\end{array}$ & $\begin{array}{c}\text { Yes } \\
\text { Yes } \\
\text { Yes } \\
\text { No } \\
9,819 \\
0.467\end{array}$ & $\begin{array}{c}\text { No } \\
\text { No } \\
\text { Yes } \\
\text { Yes } \\
2,616 \\
0.612\end{array}$ & $\begin{array}{c}\text { No } \\
\text { No } \\
\text { Yes } \\
\text { Yes } \\
1,928 \\
\text { (Pseudo) } \\
0.290\end{array}$ & $\begin{array}{c}\text { No } \\
\text { No } \\
\text { Yes } \\
\text { Yes } \\
2,616 \\
0.609\end{array}$ & $\begin{array}{c}\text { No } \\
\text { No } \\
\text { Yes } \\
\text { Yes } \\
2,576 \\
0.966\end{array}$ & $\begin{array}{c}\text { No } \\
\text { No } \\
\text { Yes } \\
\text { Yes } \\
2,560 \\
0.93\end{array}$ \\
\hline
\end{tabular}

$* * * \mathrm{p}<0.01, * * \mathrm{p}<0.05, * \mathrm{p}<0.10$, based on two-tailed tests, robust standard errors, clustered at the firm level in parentheses. (1): OLS regression with full sample, (2): Probit Regression with full sample, (3), (4), (5): OLS regression with full sample. (6): OLS regression with balanced sample, (7): Probit Regression with balanced sample, (8), (9), (10): OLS regression with balanced sample. 
Table 3: Capital Constraints and CSR Performance: Sub-Groups analysis

\begin{tabular}{||l|c||}
\hline Dependent Variable & KZ index \\
\hline CSR Index & $\mathbf{- 0 . 4 1 7 * * *}$ \\
& $\mathbf{( 0 . 0 9 0 )}$ \\
& $\mathbf{0 . 3 7 2} * *$ \\
CSR Index & $\mathbf{( 0 . 1 6 6 )}$ \\
* Least Constraint Dummy & \\
CSR Index & $\mathbf{- 0 . 4 1 3} * * *$ \\
$*$ Most Constraint Dummy & $\mathbf{( 0 . 1 0 6 )}$ \\
& \\
Size (log of total assets) & $0.126 * * *$ \\
& $(0.019)$ \\
Constant & -0.017 \\
Constant & $(0.808)$ \\
$*$ Least Constraint Dummy & $-1.390^{* * *}$ \\
Constant & $(0.103)$ \\
$*$ Most Constraint Dummy & $1.050^{* * *}$ \\
& $(0.066)$ \\
\hline Country FE & \\
Industry FE & Yes \\
Year FE & Yes \\
\hline Observations & Yes \\
R-squared & 10,078 \\
\hline
\end{tabular}

$* * * \mathrm{p}<0.01, * * \mathrm{p}<0.05, * \mathrm{p}<0.10$, based on two-tailed tests, robust standard errors, clustered at the firm level in parentheses.
Table 4: Capital Constraints and CSR Performance: Rating as a shock to CSR performance

\begin{tabular}{||c|cccccc||}
\hline & Periods & $\mathrm{N}$ & $\begin{array}{c}\Delta \mathrm{KZ} \text { for } \\
\text { High CSR }\end{array}$ & $\begin{array}{c}\Delta \mathrm{KZ} \text { for } \\
\text { Low CSR }\end{array}$ & $\begin{array}{c}\text { Diffs-in- } \\
\text { diffs }\end{array}$ & p-value \\
\hline \multirow{3}{*}{$\begin{array}{l}\text { Index } \\
\text { Index }\end{array}$} & $\mathrm{t}, \mathrm{t}+1$ & 210 & -0.01 & 0.10 & 0.11 & 0.041 \\
& $\mathrm{t}, \mathrm{t}+2$ & 200 & 0.03 & 0.16 & 0.13 & 0.043 \\
& $\mathrm{t}, \mathrm{t}+3$ & 186 & 0.05 & 0.19 & 0.14 & 0.040 \\
\hline \multirow{3}{*}{$\Delta \mathbf{K Z}$} & $\mathrm{t}, \mathrm{t}+1$ & 210 & 0.15 & -0.12 & -0.27 & 0.020 \\
& $\mathrm{t}, \mathrm{t}+2$ & 200 & -0.05 & -0.27 & -0.22 & 0.023 \\
& $\mathrm{t}, \mathrm{t}+3$ & 186 & 0.06 & -0.29 & -0.35 & 0.011 \\
\hline \hline
\end{tabular}

Periods are the years between which the change in the $\mathrm{KZ}$ index is calculated. $\mathrm{N}$ is the number of pairs in each group. High CSR includes firms that ASSET 4 initiated coverage and they are matched to firms in the Low CSR group by industry, country and KZ index at time t. Low CSR group includes firms that ASSET4 initiated coverage and they have lower CSR performance compared to the High CSR group. 
Table 5: Capital Constraints and CSR Performance:

Instrumental Variables and Simultaneous Equations Specifications

\begin{tabular}{|c|c|c|c|c|}
\hline & \multicolumn{2}{|c|}{ Instrumental Variables } & \multicolumn{2}{|c|}{ Simultaneous Equations } \\
\hline & $\begin{array}{c}\text { First Stage } \\
\text { (1) }\end{array}$ & $\begin{array}{l}K Z \text { Index } \\
\text { (2) }\end{array}$ & $\begin{array}{l}\text { KZ Index } \\
\text { (3) }\end{array}$ & $\begin{array}{l}\text { CSR Index } \\
\text { (4) }\end{array}$ \\
\hline CSR Index & & $\begin{array}{c}-2.348 * * * \\
(0.814)\end{array}$ & $\begin{array}{c}-1.545 * * * \\
(0.435)\end{array}$ & \\
\hline KZ Index & & & & $\begin{array}{c}-0.048 * * * \\
(0.007)\end{array}$ \\
\hline $\begin{array}{l}\text { Country Year Mean of CSR } \\
\text { (1st Instrument for CSR) }\end{array}$ & $\begin{array}{l}0.127 * * \\
(0.052)\end{array}$ & & & $\begin{array}{l}0.122 * * * \\
(0.039)\end{array}$ \\
\hline $\begin{array}{l}\text { Country Sector Mean of CSR } \\
\text { (2nd Instrument for CSR) }\end{array}$ & $\begin{array}{l}0.512 * * * \\
(0.050)\end{array}$ & & & $\begin{array}{l}0.455^{* * *} * \\
(0.031)\end{array}$ \\
\hline $\begin{array}{l}\text { Country Year Mean of KZ } \\
\text { (1st Instrument for KZ) }\end{array}$ & & & $\begin{array}{c}-0.113 * * * \\
(0.043)\end{array}$ & \\
\hline $\begin{array}{l}\text { Country Sector Mean of KZ } \\
\text { (2nd Instrument for KZ) }\end{array}$ & & & $\begin{array}{l}0.538 * * * \\
(0.035)\end{array}$ & \\
\hline Size & $\begin{array}{l}0.092 * * * \\
(0.003)\end{array}$ & $\begin{array}{l}0.346^{* * *} \\
(0.080)\end{array}$ & $\begin{array}{l}0.259 * * * \\
(0.043)\end{array}$ & $\begin{array}{l}0.098 * * * \\
(0.002)\end{array}$ \\
\hline Constant & & & $\begin{array}{l}-1.170 \\
(1.840)\end{array}$ & $\begin{array}{c}-0.807 * * * \\
(0.225)\end{array}$ \\
\hline Country fixed effects & Yes & Yes & Yes & Yes \\
\hline Industry fixed effects & Yes & Yes & Yes & Yes \\
\hline Year fixed effects & Yes & Yes & Yes & Yes \\
\hline Observations & 10,078 & 10,078 & 10,078 & 10,078 \\
\hline (Centered) R-squared & 0.313 & 0.001 & 0.232 & 0.477 \\
\hline $\begin{array}{l}\text { Kleibergen-Raap rk LM statistic } \\
\text { (Underidentification test) } \\
\text { Kleibergen-Raap rk Wald F Statistic } \\
\text { (Weak identification test) } \\
\text { Hansen J statistic } \\
\text { (Overidentification test) }\end{array}$ & & $\begin{array}{c}63.957 \\
(\mathrm{p}=0.000) \\
54.947 \\
0.058 \\
(\mathrm{p}=0.789)\end{array}$ & & \\
\hline $\begin{array}{l}* * * \mathrm{p}<0.01, * * \mathrm{p}<0.05, * \mathrm{p}<0.10, \text { based on } \\
\text { parentheses. Note: Columns (1) and (2): Reg } \\
\text { two variables (country-year mean of CSR an } \\
\text { regressor CSR Index. The dependent variable } \\
\text { CSR_CY }_{\text {it }} \text { and CSR_CS } \text { it }_{\text {it }} \text { Columns ( } 3 \text { ) and ( } \\
\text { employing two variables (the country-year m } \\
\text { Index and KZ Index). Thus, Column (3): KZ } \\
+\mathrm{d}_{1} \mathrm{KZ}_{\mathrm{it}}+\mathrm{d}_{2} \text { CSR_CY } \\
\text { it }+\mathrm{d}_{3} \text { CSR_CS }\end{array}$ & $\begin{array}{l}\text { D-tailed tests, } \mathrm{r} \\
\text { sion using two } \\
\text { ountry-sector } \mathrm{m} \\
\text { KZ Index. Thu } \\
\text { simultaneous re } \\
\text { and the countr } \\
\mathrm{c}_{0}+\mathrm{c}_{1} \mathrm{CSR}_{\mathrm{it}}+\mathrm{C}\end{array}$ & $\begin{array}{l}\text { ust standard e } \\
\text { ep feasible eff } \\
\text { in of CSR) as } \\
\mathrm{KZ}_{\text {it }}=\mathrm{a}_{0}+\mathrm{a}_{1} \\
\text { ession using t } \\
\text { ector mean) } \mathrm{f} \\
\mathrm{KZ} \mathrm{CY}_{\text {it }}+\mathrm{c}_{3}\end{array}$ & $\begin{array}{l}\text { e instruments } \\
\mathrm{SR}_{\text {it }} \text { where } \mathrm{C} \\
\text { ee-stage leas } \\
\text { each endoge }\end{array}$ & $\begin{array}{l}\text { he firm level in } \\
\text { tion, employing } \\
\text { the endogenous } \\
\text { instrumented by } \\
\text { lares estimation } \\
\text { regressor }(\mathrm{CSR} \\
\text { an }(4) \mathrm{CSR}_{\mathrm{it}}=\mathrm{d}\end{array}$ \\
\hline
\end{tabular}


Table 6: Capital Constraints and CSR Performance: Stakeholder Engagement and Disclosure

\begin{tabular}{|c|c|c|c|c|}
\hline Independent Variables & $\begin{array}{l}\text { Engagement } \\
\text { (1) }\end{array}$ & $\begin{array}{l}\text { Disclosure } \\
\text { (2) }\end{array}$ & $\begin{array}{c}\text { Engagement and } \\
\text { Disclosure } \\
\text { (3) }\end{array}$ & $\begin{array}{c}\text { Engagement and } \\
\text { Disclosure } \\
(4)\end{array}$ \\
\hline Stakeholder Engagement & $\begin{array}{c}-0.005 * * * \\
(0.001)\end{array}$ & & $\begin{array}{c}-\mathbf{- 0 . 0 0 3} * * * \\
(0.001)\end{array}$ & $\begin{array}{c}-0.002 * * \\
(0.001)\end{array}$ \\
\hline CSR Disclosure & & $\begin{array}{c}-4.264 * * * \\
(0.432)\end{array}$ & $\begin{array}{c}-3.918 * * * \\
(0.455)\end{array}$ & $\begin{array}{c}-4.081 * * * \\
(0.467)\end{array}$ \\
\hline $\begin{array}{l}\text { Inverse Financial Accounting } \\
\text { Quality }\end{array}$ & & & & $\begin{array}{l}3.723 * * \\
(1.804)\end{array}$ \\
\hline Size & $\begin{array}{c}0.164 * * * \\
(0.026)\end{array}$ & $\begin{array}{l}0.215 * * * \\
(0.026)\end{array}$ & $\begin{array}{l}0.229 * * * \\
(0.027)\end{array}$ & $\begin{array}{l}0.233 * * * \\
(0.028)\end{array}$ \\
\hline Constant & $\begin{array}{c}-3.156 * * * \\
(0.330)\end{array}$ & $\begin{array}{c}-2.721 * * * \\
(0.334)\end{array}$ & $\begin{array}{c}-2.834 * * * \\
(0.335)\end{array}$ & $\begin{array}{l}-0.229 \\
(0.249)\end{array}$ \\
\hline $\begin{array}{l}\text { Country fixed effects } \\
\text { Industry fixed effects } \\
\text { Year fixed effects }\end{array}$ & $\begin{array}{l}\text { Yes } \\
\text { Yes } \\
\text { Yes }\end{array}$ & $\begin{array}{l}\text { Yes } \\
\text { Yes } \\
\text { Yes }\end{array}$ & $\begin{array}{l}\text { Yes } \\
\text { Yes } \\
\text { Yes }\end{array}$ & $\begin{array}{l}\text { Yes } \\
\text { Yes } \\
\text { Yes }\end{array}$ \\
\hline $\begin{array}{l}\text { Observations } \\
\text { R-squared }\end{array}$ & $\begin{array}{l}9,812 \\
0.196\end{array}$ & $\begin{array}{l}9,812 \\
0.212\end{array}$ & $\begin{array}{l}9,812 \\
0.213\end{array}$ & $\begin{array}{l}9,224 \\
0.223\end{array}$ \\
\hline
\end{tabular}

(1), (2), (3) and (4): OLS regressions with full sample, where the dependent variable is the KZ index. *** p<0.01, ** $\mathrm{p}<0.05, * \mathrm{p}<0.10$, based on two-tailed tests, robust standard errors, clustered at the firm level in parentheses.

Table 7: Capital Constraints and CSR Performance: By Factors

\begin{tabular}{|c|c|c|c|c|}
\hline & $\begin{array}{l}\text { KZ Index } \\
\text { (1) }\end{array}$ & $\begin{array}{l}\text { KZ Index } \\
\text { (2) }\end{array}$ & $\begin{array}{l}\text { KZ Index } \\
\text { (3) }\end{array}$ & $\begin{array}{c}\text { KZ Index } \\
\text { (4) }\end{array}$ \\
\hline Environmental & $\begin{array}{c}-0.770 * * * \\
(0.087)\end{array}$ & & & $\begin{array}{c}-0.495 * * * \\
(0.100)\end{array}$ \\
\hline Social & & $\begin{array}{c}-0.727 * * * \\
(0.084)\end{array}$ & & $\begin{array}{c}-0.444 * * * \\
(0.097)\end{array}$ \\
\hline Corporate Governance & & & $\begin{array}{c}-0.397 * * * \\
(0.118)\end{array}$ & $\begin{array}{c}0.060 \\
(0.121)\end{array}$ \\
\hline Size & $\begin{array}{c}0.211 * * * \\
(0.026)\end{array}$ & $\begin{array}{c}0.208 * * * \\
(0.027)\end{array}$ & $\begin{array}{c}0.146 * * * \\
(0.026)\end{array}$ & $\begin{array}{c}0.228 * * * \\
(0.027)\end{array}$ \\
\hline Constant & $\begin{array}{c}0.323 \\
(0.789) \\
\end{array}$ & $\begin{array}{c}0.576 \\
(0.798) \\
\end{array}$ & $\begin{array}{r}0.749 \\
(0.772) \\
\end{array}$ & $\begin{array}{c}0.371 \\
(0.799) \\
\end{array}$ \\
\hline $\begin{array}{l}\text { Country fixed effects } \\
\text { Industry fixed effects } \\
\text { Year fixed effects }\end{array}$ & $\begin{array}{l}\text { Yes } \\
\text { Yes } \\
\text { Yes } \\
\end{array}$ & $\begin{array}{l}\text { Yes } \\
\text { Yes } \\
\text { Yes } \\
\end{array}$ & $\begin{array}{l}\text { Yes } \\
\text { Yes } \\
\text { Yes } \\
\end{array}$ & $\begin{array}{l}\text { Yes } \\
\text { Yes } \\
\text { Yes } \\
\end{array}$ \\
\hline $\begin{array}{l}\text { Observations } \\
\text { Adjusted R-squared }\end{array}$ & $\begin{array}{l}10,078 \\
0.212 \\
\end{array}$ & $\begin{array}{l}10,078 \\
0.212 \\
\end{array}$ & $\begin{array}{l}10,078 \\
0.200 \\
\end{array}$ & $\begin{array}{l}10,078 \\
0.215 \\
\end{array}$ \\
\hline
\end{tabular}

(1), (2), (3) and (4): OLS regressions with full sample, where the dependent variable is the KZ index. *** p<0.01, ** $\mathrm{p}<0.05, * \mathrm{p}<0.10$, based on two-tailed tests, robust standard errors, clustered at the firm level in parentheses. 


\section{APPENDIX}

\section{Construction of the KZ, SA and WW Indices}

We calculate the KZ index following Baker, Stein and Wurgler (2003) as follows:

$K Z$ index $=-1.002 C F_{i t} / A_{i t-1}-39.368 D I V_{i t} / A_{i t-1}-1.315 C_{i t} / A_{i t-1}+3.139 L E V_{i t}+0.283 Q_{i t}$,

where $\mathrm{CF}_{\mathrm{it}} / \mathrm{A}_{\mathrm{it}-1}$ is cash flow over lagged assets; $\mathrm{DIV}_{\mathrm{it}} / \mathrm{A}_{\mathrm{it}-1}$ is cash dividends over lagged assets; $\mathrm{C}_{\mathrm{it}} / \mathrm{A}_{\mathrm{it}-1}$ is cash balances over assets; $\mathrm{LEV}_{\mathrm{it}}$ is leverage and $\mathrm{Q}_{\mathrm{it}}$ is the market value of equity (price times shares outstanding plus assets minus the book value of equity over assets. The original ordered logit regression and full exposition of the index may be found in Kaplan and Zingales (1997). Higher values of the KZ index imply that the firm is more capital constrained. The intuition behind these variables is that firms with high cash flows and large cash balances have more internal funds to deploy for new projects and as a result they are less capital constrained (Baker et al., 2003). Firms with high dividend payments and low market-to-book have fewer growth options and investment opportunities and as a result they do not need as much new financing (Lamont et al, 2001). Finally, firms with high leverage are less capable of obtaining more debt financing because the probability of default is already high and as a result the cost of financing is high as well (Baker et al., 2003).

We derive the SA Index based on Hadlock and Pierce (2010) using the following equation: SA Index $=(-0.737 *$ Size $)+\left(0.043 *\right.$ Size $\left.^{\wedge} 2\right)-(0.040 *$ Age $)$, where Size is measured as the logged value of inflation adjusted (to 2004) book assets. Moreover, the WW Index is based on Whitted and $\mathrm{Wu}$ (2006) and derived as follows: $W W$ Index $=(-0.091 * C F)-(0.062 *$ DIVPOS $)+(0.021 * T L T D)-(0.044 * L N T A)+(0.102 * I S G)-(0.035 * S G)$, where $\mathrm{CF}$ is the ratio of cash flow to total assets; DIVPOS is an indicator that takes the value of one if the firm pays cash dividends; TLTD is the ratio of the long-term debt to total assets; 
LNTA is the natural log of total assets, ISG is the firm's 3-digit industry sales growth; SG is firm sales growth.

\section{Table: Pearson correlations $(\mathrm{N}=\mathbf{1 0 , 0 7 8})$}

\begin{tabular}{|c|l|c|c|c|c|c|c|}
\hline \multicolumn{2}{|c|}{ Variable } & 1 & 2 & 3 & 4 & 5 & 6 \\
\hline 1 & KZ index & 1.00 & & & & & \\
\hline 2 & No Repurchase Indicator & $\begin{array}{c}0.03 \\
(0.00)\end{array}$ & 1.00 & & & & \\
\hline 3 & SA Index & $\begin{array}{c}-0.18 \\
(0.00)\end{array}$ & $\begin{array}{c}0.09 \\
(0.00)\end{array}$ & 1.00 & & & \\
\hline 4 & WW Index & $\begin{array}{c}0.01 \\
(0.40)\end{array}$ & $\begin{array}{c}0.11 \\
(0.00)\end{array}$ & $\begin{array}{c}0.91 \\
(0.00)\end{array}$ & 1.00 & & \\
\hline 5 & CSR Index & $\begin{array}{c}-0.05 \\
(0.00)\end{array}$ & $\begin{array}{c}-0.04 \\
(0.00)\end{array}$ & $\begin{array}{c}-0.43 \\
(0.00)\end{array}$ & $\begin{array}{c}-0.42 \\
(0.00)\end{array}$ & 1.00 & \\
\hline 6 & Stakeholder Engagement & $\begin{array}{c}-0.07 \\
(0.00)\end{array}$ & $\begin{array}{c}0.00 \\
(0.70)\end{array}$ & $\begin{array}{c}-0.35 \\
(0.00)\end{array}$ & $\begin{array}{c}-0.36 \\
(0.00)\end{array}$ & $\begin{array}{c}0.50 \\
(0.00)\end{array}$ & 1.00 \\
\hline 7 & CSR Disclosure & $\begin{array}{c}-0.12 \\
(0.00)\end{array}$ & $\begin{array}{c}-0.04 \\
(0.00)\end{array}$ & $\begin{array}{c}-0.24 \\
(0.00)\end{array}$ & $\begin{array}{c}-0.25 \\
(0.00)\end{array}$ & $\begin{array}{c}0.68 \\
(0.00)\end{array}$ & $\begin{array}{c}0.39 \\
(0.00)\end{array}$ \\
\hline 8 & Environmental & $\begin{array}{c}-0.02 \\
(0.03)\end{array}$ & $\begin{array}{c}-0.06 \\
(0.00)\end{array}$ & $\begin{array}{c}0.47 \\
(0.00)\end{array}$ & $\begin{array}{c}-0.50 \\
(0.00)\end{array}$ & $\begin{array}{c}0.81 \\
(0.00)\end{array}$ & $\begin{array}{c}0.44 \\
(0.00)\end{array}$ \\
\hline 9 & Social & $\begin{array}{c}-0.07 \\
(0.00)\end{array}$ & $\begin{array}{c}-0.03 \\
(0.00)\end{array}$ & $\begin{array}{c}-0.44 \\
(0.00)\end{array}$ & $\begin{array}{c}-0.46 \\
(0.00)\end{array}$ & $\begin{array}{c}0.89 \\
(0.00)\end{array}$ & $\begin{array}{c}0.49 \\
(0.00)\end{array}$ \\
\hline 10 & Corporate Governance & $\begin{array}{c}-0.01 \\
(0.23)\end{array}$ & $\begin{array}{c}-0.01 \\
(0.21)\end{array}$ & $\begin{array}{c}-0.09 \\
(0.00)\end{array}$ & $\begin{array}{c}-0.02 \\
(0.06)\end{array}$ & $\begin{array}{c}0.63 \\
(0.00)\end{array}$ & $\begin{array}{c}0.25 \\
(0.00)\end{array}$ \\
\hline 11 & Size & $\begin{array}{c}0.18 \\
(0.00)\end{array}$ & $\begin{array}{c}-0.09 \\
(0.00)\end{array}$ & $\begin{array}{c}-1.00 \\
(0.00)\end{array}$ & $\begin{array}{c}-0.92 \\
(0.00)\end{array}$ & $\begin{array}{c}0.43 \\
(0.00)\end{array}$ & $\begin{array}{c}0.36 \\
(0.00)\end{array}$ \\
\hline
\end{tabular}

\begin{tabular}{|c|l|c|c|c|c|c||}
\hline \multicolumn{2}{|c|}{ Variable } & 7 & 8 & 9 & 10 & 11 \\
\hline \hline 7 & CSR Disclosure & 1.00 & & & & \\
\hline 8 & Environmental & $\begin{array}{c}0.45 \\
(0.00)\end{array}$ & 1.00 & & & \\
\hline 9 & Social & $\begin{array}{c}0.57 \\
(0.00)\end{array}$ & $\begin{array}{c}0.73 \\
(0.00)\end{array}$ & 1.00 & & \\
\hline 10 & Corporate Governance & $\begin{array}{c}0.57 \\
(0.00)\end{array}$ & $\begin{array}{c}0.14 \\
(0.00)\end{array}$ & $\begin{array}{c}0.35 \\
(0.00)\end{array}$ & 1.00 & \\
\hline 11 & Size & $\begin{array}{c}0.24 \\
(0.00)\end{array}$ & $\begin{array}{c}0.47 \\
(0.00)\end{array}$ & $\begin{array}{c}0.44 \\
(0.00)\end{array}$ & $\begin{array}{c}0.09 \\
(0.00)\end{array}$ & 1.00 \\
\hline
\end{tabular}

